\title{
LA SÁTIRA EN EL TIEMPO
}

\author{
JUAN CAMPESINO \\ Centro Nacional de Investigación, Documentación e Información Teatral Rodolfo Usigli \\ Ciudad de México
}

\section{Los peludos}

Si el significado original de la palabra parodia se oscurece a causa de la ambivalencia cualitativa del prefijo para1, en el caso de la sátira el escollo reviste también un carácter cuantitativo, toda vez que la duplicidad se origina

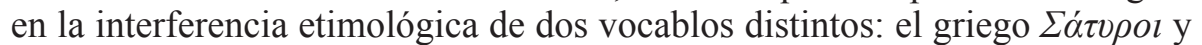
el latino satura. Será en su De satyrica graecorvm poesi et romanorvm satira, de $1605^{2}$, donde el ginebrino Isaac Casaubon se ocupe por primera vez de la confusión ${ }^{3}$ (que se remonta a Donato, a comienzos del medievo, pasa por Isidoro de Sevilla y se cuela al renacimiento por la vía de Escalígero) para desligar, si no por completo, sí en lo esencial, las Romanae Saturae de la Graecorum satyrica.

1 Véanse F. Householder, «ПАР $\Omega I \Delta I A »$, Journal of Classical Philology, 39, 1, 1944, pág. 2 , y F. J. Lelièvre, «The Basis of Ancient Parody», Greece and Rome, 1, 2, 1954, pág. 66 y sigs.

2 I. Casaubon, De satyrica graecorvm poesi et romanorvm satira, J. J. Gebavari Vidvam et Filivm, Halle, 1774, pág. LXIII y sigs.

${ }^{3} \mathrm{Si}$ es que se la puede llamar así, ya que, como señala George Hendrickson, la verdadera etimología del vocablo latino satura se ha perdido. Véase «Satura Tota Nostra Est», Classical Philology, 22, 1, 1927, pág. 59. 
Por cuanto a esta última, la referencia más antigua a los sátiros ( $\gamma \varepsilon ́ v o \varsigma$

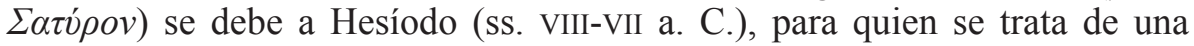
clase de númenes inútiles, enemigos del trabajo, hijos de las cinco nietas de Foroneo (producto de los amoríos de su hija Ctonia con Hecátero), de quienes también descenderían las ninfas y diosas montesas y los denominados curetes ${ }^{4}$. No obstante, en el Cíclope de Eurípides $^{5}$ (s. v a. C.), Sileno los reclama hijos suyos e, incluso, un autor más reciente como Nono de Panópolis (ss. IV o v) los atribuye a la unión de Hermes e Iftima, hija de Doro 6 . Pertenecen, cosa segura, a las cortes de Baco, junto a quien aparecen, a finales del siglo VI a. C., en el sílice Würzburg7 ${ }^{7}$, representados como hombres barbados e itifálicos, con cola y orejas de burro o caballo, acompañados de bacantes y de la inscripción « $\triangle A T P Y B \Omega \rrbracket$, que un filólogo como Roy Flickinger considera una simple errata en sustitución de $\sigma \alpha ́ \tau v \rho o \varsigma^{8}$, pero que bien pudiera tener relación con los satras ( $\Sigma \alpha ́ \tau \rho \alpha \imath)$, pueblo balcánico del que dice Herodoto que adoraba a $\mathrm{Baco}^{9}$, y que para el topógrafo William Leake constituye el antecedente directo de los sátiros ${ }^{10}$. Según Ridgeway, los satras se distinguían por la práctica de bacanales y de una moral licenciosa, circunstancias que habrían derivado en las cualidades orgiásticas de los sátiros ${ }^{11}$. Si no su procedencia exacta, su origen levantino parece confirmarlo la influencia oriental que, en el siglo VII a. C., condujo a la transformación radical de las figuras decorativas que aparecen en las reliquias de la época, pasando de las formas geométricas e icónicas a la representación detallada de personajes, deidades y criaturas mitológicas ${ }^{12}$, como la figura antropomorfa de rostro monstruoso y cubierta de pelaje que, en los restos de una vasija protoática de $670 \mathrm{a}$. C., acompaña a dos varones danzantes, probablemente relacionados con el culto a Dionisio, o el personaje itifálico que acosa a una dama con un garrote en una vasija protocorintia de 650 a. C.13

Además de atender a la domesticación de los sátiros que se aprecia en la cerámica de los siglos VII y VI a. C., el libro de Isler-Kerényi inicia con un preámbulo en el que Othmar Keel subraya la influencia palestina en el arte griego de la época para sugerir que las raíces de la genealogía trazada por

${ }^{4}$ Estrabón, x 3, 19. Reproducido en K. Goettling (ed.), Hesiodi carmina, Hennings, Gotha y Erfurt, 1831, pág. 225, y en R. Merkelbach y M. Litchfield (eds.), Fragmenta Hesiodea, Clarendon, Oxford, 1967, pág. 60.

${ }^{5}$ Vv. 13, 82, 269.

${ }^{6}$ Dionisiacas, XIV, 113-14.

${ }^{7}$ Véase W. Ridgeway, The Origin of Tragedy with Special Reference to the Greek Tragedians, Cambridge University Press, 1910, pág. 12.

8 Véase R. Flickinger, «Tragedy and the Satyric Drama», Classical Philology, 8, 3, 1913, pág. 278.

${ }^{9}$ VII 3,111

${ }^{10}$ Cf. W. M. Leake, Travels in Northern Greece, III, Rodwell, Londres, 1835, pág. 190.

${ }^{11}$ Véase supra, n. 7.

${ }^{12}$ Apud C. Isler-Kerényi, Civilizing Violence: Satyrs on 6th-Century Greek Vases (trad. de E. de Sena), Göttingen, Friburgo, 2004, pág. 7.

${ }^{13}$ Cf. loc. cit., págs. 8-9. 
la autora pudieran remontarse a aquellos demonios-cabra llamados śé îrîm (plural de śă $i r$ ), «los peludos», que menciona más de una vez el Antiguo Testamento ${ }^{14}$. En adición a su doble anatomía, los sátiros comparten con estos seres la afición al baile y la caza ${ }^{15}$, lo que se suma a la semejanza fonética de los apelativos y, caso de los segundos, la alternancia ocasional del sinónimo şāpî́r ${ }^{16}$. Por cuanto a las cualidades equinas de unos y caprinas de los otros, lo cierto es que las criaturas griegas que acompañan al flautista en el vaso Pandora (s. V a. C.) cuentan ya con cola, cuernos y pezuñas de cabra ${ }^{17}$, elementos que a la postre se integrarían a la iconografía típica de los sátiros, pese a que, todavía a finales de ese siglo, en un vaso napolitano, se los halla con cola de asno o caballo ${ }^{18}$.

De manera paralela, las evidencias literarias hablan de criaturas a todas luces simposiacas. Ya Horacio (s. I a. C.) señala la función del coro en el Polifemo de Eurípides, formado de sátiros que, mientras bailaban al son de la flauta, recitaban chanzas jocosas relativas a la acción del drama ${ }^{19}$, y en su versión, de comienzos del siglo XVIII, de la epístola a los pisones, Joseph de Jouvancy asegura que, luego del drama trágico, en los certámenes de teatro se representaba una pieza jocoseria que incluía un coro de sátiros al frente del que figuraba Sileno, este último dedicado a urdir intrigas entre dioses y héroes ${ }^{20}$. En efecto, la presencia de Sileno, a quien se representaba como un viejo calvo y obeso montado en un asno ${ }^{21}$, parece una constante del drama satírico del siglo v a. C.22; así en los Icneutas, de Sófocles, donde también figura como

${ }^{14} V$. gr. Isaías, 13, 21-22; 34, 9-15; Levítico, 17, 7-10.

15 Véase O. Keel, «Preamble» a C. Isler-Kerényi, op. cit., págs. VIII-IX.

16 Véase B. Janowski, «Satyrs», en K. van der Torn, B. Becking and P. van der Horst (eds.), Dictionary of Deities and Demons in the Bible, Brill, Leiden, 1999, págs. 732-733. Siendo así, el hecho de que la Versión del Rey Jaime de la Biblia (1611) se refiera a estos númenes como «satyrs» pudiera resultar no del todo arbitrario.

17 Véanse A. H. Smith, «The Making of Pandora», The Journal of Hellenic Studies, 11, 1890, págs. 279-280, y en el mismo número, las ilustraciones XI y XII.

${ }^{18}$ Véase R. Flickinger, art. cit., pág. 279. Ya en 1880, Adolf Furtwängler hizo notar que los sátiros de apariencia equina provienen de Asia Menor, el norte de Grecia y el Ática, mientras que los de aspecto caprino son originarios del Peloponeso. Véase loc. cit., pág. $278 \mathrm{n}$. Por otra parte, Herodoto (IV, 25) habla de un pueblo, cuya existencia al norte del Cáucaso, en las cercanías de la Escitia, pone en entredicho, habitado por hombres con pies de cabra a los que da el nombre de egípodas ( $\alpha i \gamma i \pi o \delta \alpha \varsigma$ ).

${ }^{19}$ Cf. Arte poética, vv. 220-226.

${ }^{20}$ Apud J. Goya y Muniain, «Notas» a Aristóteles, El arte poética, Espasa-Calpe, Madrid, 1970, pág. 103.

21 Véase «Sileno», en M. Izzi, Diccionario ilustrado de los monstruos, Alejandría, Mallorca y Barcelona, 1996, pág. 440.

${ }^{22}$ En su artículo «A Handlist of Satyr Plays» (Harvard Studies in Classical Philology, 78, 1974, págs. 107-143), Dana Ferrin Sutton ofrece un valioso recuento de los fragmentos que, según los eruditos, corresponden a dramas satíricos, mismo que acompaña con un análisis crítico de los motivos que han redituado en ello. 
padre de los sátiros ${ }^{23}$. Hijo de Hermes o Pan, educador de Dionisio, su nombre deriva en el genérico «silenos» ${ }^{24}$, una clase de genios acuíferos que ya aparece en concubinato con las ninfas en un Himno a Afrodita ${ }^{25}$. De hecho, la inscripción «IIIENOI», «silenos», rotula las tres figuras con extremidades equinas que escoltan a Hefesto en el vaso Françoise, de principios del siglo vi a. C.26, por lo que es de suponer que «sátiro» y «sileno» llegaran a referirse indistintamente a una misma clase de criaturas $^{27}$.

En un polémico pasaje de su Poética $^{28}$, señala Aristóteles que, en adición a su léxico jocoso, la poesía satírica constaba de versos de ocho pies por ser más propicios al baile, pero que, al ganar dignidad el argumento y trabar conversación los personajes, el drama evolucionó del tetrámetro trocaico al yambo, por tratarse este último del metro más natural de la lengua griega. El postulado resulta controversial porque, a la falta de pruebas, se suma el hecho de que sitúa la transformación en el seno de la tragedia que, si no del drama satírico como tal, habría evolucionado del estilo satírico propio de las danzas dionisiacas, lo que contrasta con lo afirmado por el estagirita unas líneas arriba, cuando dice que, conforme la poesía crecía en dignidad, al tiempo que los yambógrafos se inclinaban por la comedia ${ }^{29}$, los autores épicos (léase de hexámetros homéricos) se ocuparon de componer tragedias, género que, con todo, habría tenido su origen en el ditirambo de los solistas corales ${ }^{30}$. Sin embargo, para Gerald Else no hay contradicción alguna, toda vez que, apunta, con la palabra «satírico»

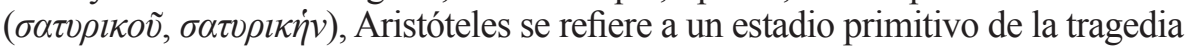

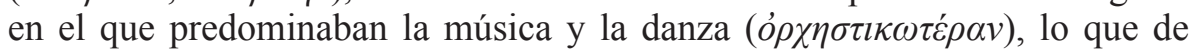
ningún modo se opone a su grave origen ${ }^{31}$.

\section{Satura quidem tota Romana est}

Por lo que hace al segundo término, hoy día nadie parece dudar de que el nombre latino satura significaba originalmente «miscelánea», «variedad». Los desacuerdos surgen, no obstante, a la hora de fijar su origen etimológico, ya que la ausencia de terminación nominal latina en -ǔra sugiere que se trata

23 Véase Sófocles, Fragmentos (trad. de J. M. Lucas), Gredos, Madrid, 1983, págs. 153-178.

${ }^{24}$ Véase «Silen», en G. Jobes, Dictionary of Mithology, Folklore and Symbols, II, Scarecrow Press, Nueva York, 1962, pág. 1453.

${ }^{25}$ Véase Himnos homéricos, v, vv. 262-63.

${ }^{26}$ Véase R. Flickinger, art. cit., pág. 278.

${ }^{27}$ Apud J. Larson, Greek Nymphs: Myth, Cult, Lore, Oxford University Press, Nueva York, 2001, págs. 91-96.

${ }^{28}$ Cf. 1449a, 20-25.

${ }^{29}$ El yambo, dice, lo emplean obras como el Margites porque resulta un metro propicio

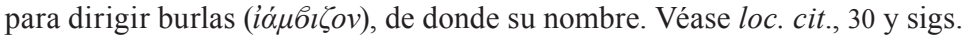

${ }^{30}$ Cf. loc. cit., 4-15.

${ }^{31}$ Cf. G. F. Else, «Aristotle and Satyr-Play I», Transactions and Proceedings of the American Philological Association, 70, 1939, pág. 156. 
de un término derivado ${ }^{32}$. Hendrickson atribuye su origen a la locución adverbial per saturam ${ }^{33}$, mientras que su contemporáneo Berthold Ullman lo deriva del adjetivo satur, «lleno» ${ }^{34}$, opinión, comúnmente aceptada hoy día ${ }^{35}$, que comparte un autor más reciente como Charles Witke, argumentando que, de las cuatro posibles etimologías que, siguiendo a Suetonio ${ }^{36}$ (ss. I-II), propone Diomedes (s. IV) para el término literario satura ${ }^{37}$, las tres últimas parten de un nexo asumido entre el adjetivo satur, «lleno», y el sustantivo satura, género de poemas mezclados o misceláneos ${ }^{38}$.

Por cuanto a la primera posibilidad de Diomedes, la falta de evidencias

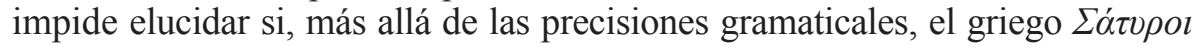
tuvo que ver en la formación del latín satura, satur o per saturam, aunque cabe mencionar la coincidencia de que así como el nombre griego hace sus primeras apariciones en plural, Ullman asegura que el latín satura constituía un femenino singular colectivo, probablemente derivado, como otros, de un plural neutro, que «en algún momento de su historia se convirtió en un sustantivo abstracto que significaba "llenura", tal vez dando nombre a la deidad local llamada Satura ${ }^{39}$. En lo tocante a la segunda posibilidad, la ocurrencia más antigua del adjetivo satur se halla en un himno de los Arvales, sacerdocio consagrado a Ceres cuyos orígenes se remontarían al siglo vIII a. C. ${ }^{40} \mathrm{~A}$ propósito, Robert

32 Apud M. Coffey, Roman Satire, Methuen, Londres, 1976, pág. 11.

${ }_{33}$ De hecho, el filólogo estadounidense rastrea el empleo de per saturam, que aparece en un fragmento de Lucilio (véase F. Marx, ed., Lucilii carminum reliquiae, Teubner, Lipsia, I, 1904, frag. 48, pág. 6), hasta llegar a Cayo Gaelio, a comienzos del siglo II a. C. (cf. G. Hendrickson, «Satura-The Genesis of a Literary Form», Classical Philology, 6, 2, 1911, pág. 136). En opinión de Robert Henning Webb, lo más probable es que el recorrido de la etimología haya sido inverso, yendo del sustantivo satura a la locución per saturam. Véase «On the Origin of Roman Satire», Classical Philology, 7, 2, 1912, pág. 182.

${ }^{34}$ Cf. B. L. Ullman, «Satura and Satire», Classical Philology, 8, 2, 1913, pág. 172 y sigs.

${ }_{35}$ V. gr., P. A. Miller, «Introduction» to Latin Verse Satire: An Anthology and Critical Reader, Routledge, Nueva York, 2005, pág. 4, y K. Freudenburg, The Cambridge Companion to Roman Satire, Cambridge University Press, Nueva York, 2005, págs. 2, 84.

${ }^{36}$ Para una indagación en torno a las fuentes restantes empleadas por Diomedes en el pasaje, véase C. A. van Rooy, Studies in Classical Satire and Related Literary Theory, Brill, Leiden, 1965, pág. 1 y sigs.

${ }^{37}$ A saber: (1) el sustantivo Satyri, del griego Látvpol discutido en el apartado precedente, por tratarse de una clase de poesía que, como el coro satírico, se refiere a cosas vergonzosas y risibles; (2) un platillo ritual (lanx) llamado satura y compuesto de diversas frutas, en atención a la variedad de temas que convergen en la sátira; (3) una especie de estofado (farcimen) llamado satura que, según decía Varrón en sus Cuestiones plautinas, se preparaba a base de pasas, polenta, piñones y vino con miel, y (4) una clase de leyes que, en un solo dictamen, reunían múltiples disposiciones, tal como la composición satírica reúne diversos poemas, y que, por ello, era conocida como lex o lege satura. Cf. Ars grammatica, III, en H. Keil (ed.), Grammatici latini, I, Teubner, Lipsia, 1857, págs. 486-487.

${ }^{38}$ C. Witke, Latin Satire. The Structure of Persuasion, Brill, Leiden, 1970, pág. 71.

${ }^{39}$ B. L. Ullman, art. cit., pág. 177 (mía la traducción). Se trata de la Saturae palus de que habla Virgilio. Véase Aeneida, viI, v. 801.

${ }^{40}$ Véase supra, n. 32. 
C. Elliott ha vinculado el origen de la sátira con el poder mágico asignado a la palabra en la liturgia primitiva, de donde su parentesco con la maledicencia y la invectiva ${ }^{41}$, conexión que, si probable, no pasa de ser una hipótesis ${ }^{42}$. La cuarta teoría, por su parte, se viene abajo por el simple hecho de que, como hace notar Witke, no se conocen, en el marco legal, ejemplos anteriores a Diomedes de una tal lex o lege satura, y sí de una o varias leyes per saturam o in saturam ${ }^{43}$, de donde se deduce que tanto el género literario como las legislaciones misceláneas tomaron su nombre de una misma fuente. Es, por tanto, la tercera posibilidad la de mayor certeza, así por la referencia precisa de Varrón como porque el genere farciminus del platillo mencionado habría corrido con una suerte paralela: farta, plural de fartum («estofado»), sería asimismo empleado para designar una clase de literatura, la farsa, no desligada, por lo demás, de la sátira ${ }^{44}$.

Al margen de sutilezas, todo apunta a que la locución per saturam significaba originalmente «por saturación», por lo que, en lo literario, designaba una obra compuesta por integración de diversos materiales. Es el sentido que parece tener para Ennio (ss. III y II a. C.), cuyas carmina per saturam constituyen el empleo literario más antiguo que se conoce de la locución ${ }^{45}$. En efecto,

${ }^{41}$ Cf. R. C. Elliott, The Power of Satire, Princeton University Press, 1960, págs. 3-15.

${ }^{42}$ Cf. loc. cit., págs. 87-99. Por lo que hace a la tradición griega, Elliott sostiene su teoría sobre una base triple. Recurre, en primer lugar, a la suposición de Francis Cornford, sustentada en los Acarnienses de Aristófanes (vv. 242-279), de que en los antiguos himnos fálicos, antecedente directo, según Aristóteles, de la comedia (véase Poética, 1449a, 10 y sigs.), alternaban el coro y los solistas, quienes solían dirigir sus yambos contra ciertos individuos, presumiblemente aquellos que se negaban a contribuir con la comunidad (véase The Origin of Attic Comedy, Arnold, Londres, 1914, págs. 35-52). La segunda línea de Elliott rescata la antigua creencia en el poder mágico de Arquíloco, quien, según la leyenda, con sus yambos compuestos en ocasión de los festivales de Démeter habría orillado al suicidio a Licambo y su hija Neobule tras la cancelación, al enterarse éste de que la madre de Arquíloco era una esclava, del compromiso nupcial fijado previamente para el poeta y la joven (véase Hendrickson, «Archilochus and the Victims of His Iambics», The American Journal of Philology, 46, 2, 1925, págs. 101-127). Finalmente, aunque en estrecha relación con lo anterior, Elliott se refiere al origen de la poesía del que habla Johan Huizinga (véase Homo Ludens, trad. de E. Imaz, Alianza Emece, Buenos Aires, 1972, pág. 131): «En los estados primitivos del desarrollo cultural — dice el estadounidense —, la poesía está casi siempre asociada a la magia, sea ésta blanca, negra o ambas. La función del poeta aún no ha sido diferenciada; además de ser un entusiasta o tal vez un guasón o compositor de invectivas, ha de ser también profeta, historiador, genealogista y curandero»: op. cit., pág. 10 (mía la traducción). Cabe añadir que, de manera paralela, Jean-Pierre Cèbe liga el origen de la parodia y la caricatura a la risa ritual practicada por algunos cultos arcaicos del Mediterráneo, donde, lo mismo que la invectiva en los ritos observados por Elliott (véase loc. cit., págs. 49-87), cumplía una función expiatoria. Véase J. P. Cèbe, La caricature et la parodie: Dans le monde Romain antique, des origines a Juvénal, Boccard, París, 1966, págs. 19-35.

${ }^{43}$ Op. cit., pág. 17.

44 Véase B. L. Ullman, art. cit., pág. 174. La misma suerte habría corrido el vocablo farrago («platillo variado») con el que Juvenal se refiere a sus sátiras. Véase G. Highet, The Anatomy of Satire, Princeton University Press, 1972 [1962], pág. 231.

${ }^{45}$ Apud G. Hendrickson, «Satura Tota Nostra Est», pág. 56. 
los fragmentos que se conservan de sus sátiras dan cuenta de una considerable variedad de metros, materias y tonos, la mayor parte abundante, eso sí, en reflexión sobre las costumbres, pero nada más ${ }^{46}$ : «No tienen — dice José Guillén Cabañero- el carácter de las de Lucilio, son silvas que se abren a la reflexión moral, y a la enseñanza y educación ética» ${ }^{47}$. El Luciliano charactere del que habla Varrón ${ }^{48}$ se distingue, a cambio, por la invectiva y el ataque personal ${ }^{49}$, una innovación en la que el poeta del siglo II a. C. sería imitado por Crispino y Fanio ${ }^{50}$, así como en el estilo llano y el empleo del hexámetro ${ }^{51}$, características que, ridendo dicere verum, Horacio se comprometería a perfeccionar ${ }^{52}$ y que en conjunto tasarían la estandarización literaria del término satura ocurrida, dice Hendrickson, en tiempos del venusino (40-30 a. C.) ${ }^{53}$. Como sea, lo cierto es que, amén del hexámetro, el estilo coloquial y el aspecto abiertamente punitivo son ya una constante en Juvenal (ss. I y II), para quien, ante la corrupción de su tiempo, «difficile est saturam non scribere» ${ }^{54}$. Dado que en la literatura griega no se los halla reunidos, es a ellos que se refiere Quintiliano en su famosa frase «Satura quidem tota nostra est» ${ }^{55}$, con la que reivindica el origen romano de la sátira.

Constituyen, no obstante, cualidades literarias que pueden rastrearse muchos siglos atrás; no en balde se lamenta Juvenal, a través de un mordaz interlocutor imaginario: «¿De dónde aquella franqueza de los antiguos para escribir con ánimo ardiente todo lo que querían? ${ }^{56}$. Los silos de Timón (s. III a. C.) representan, desde luego, el referente más cercano, no sólo temporalmente hablando, sino también por tratarse de hexámetros en los que la filosofía se

${ }^{46}$ Véase «Saturarum reliquiae», en J. Vahlen (ed.), Ennianae poesis reliquiae, Teubner, Lipsia, 1854, págs. 154-162.

47 J. Guillén Cabañero (ed.), La sátira latina, Akal, Madrid, 1991, pág. 35.

48 Varrón, De re rustica, III 2, 17.

${ }^{49}$ E. M. Pease sostiene, sin embargo, que las sátiras de Ennio ya incorporaban ataques personales (véase «The Satirical Element in Ennius», Transactions and Proceedings of the American Philological Association, 27, 1896, págs. XLVIII-L), pero ante la falta de evidencias más vale coincidir con Friedrich Leo en que no era así (véase supra, n. 47). Por su parte, John Svarlien argumenta que, a propósito de Lucilio, Varrón no se refiere solamente al carácter agresivo de su obra, sino a su estilo poético en el más estricto sentido del término (véase «Lucilianus Character», The American Journal of Philology, 115, 2, 1994, págs. 253-267). Así, en lo tocante a Ennio y Lucilio, Horacio opina que el estilo de éste supera al de aquél, resultando su lectura más placentera. Véase Satirae, I 10, vv. 64-67.

${ }^{50}$ Véase loc. cit., I 4, vv. 6-25; II 1, vv. 62-65.

${ }^{51}$ Cf. G. Hendrickson, «Satura-The Genesis of a Literary Form», pág. 131.

52 Véase Horacio, Satirae, I 10.

${ }^{53}$ G. L. Hendrickson, «Satura-The Genesis of a Literary Form», Classical Philology, VI, 2, 1911, pág. 138. Sermones llamaba a sus sátiras el propio Horacio.

${ }^{54}$ Horacio, Satirae I 1, v. 30. Y luego (vv. 79-80): «Si natura negat, facit indignatio uersum qualemcumque potest».

${ }_{55}$ Op. cit., X 1, 93. Con todo, el rétor de Calahorra reconoce la sátira miscelánea de Ennio. Véase loc. cit., IX 2, 36; 3, 9 .

${ }^{56}$ Op. cit., I, vv. 151-53, en Sátiras (trad. de R. Heredia), Universidad Nacional Autónoma de México, 1984, pág. 5. 
rebaja al nivel del lenguaje ordinario ${ }^{57}$. Por su parte, Horacio desprende a Lucilio de la antigua comedia ática ${ }^{58}$, y Arthur Cotterell subraya el papel de Pratinas (ss. VI y V a. C.) como inventor del drama satírico ${ }^{59}$. Para Edward Bloom, sin embargo, la invención de la sátira le corresponde a Arquíloco ${ }^{60}$ (s. VII a. C.), cuyos yambos imitaría Hiponacte un siglo después ${ }^{61}$. Sin conceder semejantes títulos, a éstos cabría sumar las fábulas de Esopo (s. VI a. C.), que Edgar Johnson incluye en su $A$ Treasury of Satire ${ }^{62}$, y desde luego, a Sócrates (s. va. C.), cuya vis satírica «se desprende del carácter y el estilo filosófico exhibido en Platón, en particular en los diálogos tempranos y, en menor medida, en otros relatos antiguos sobre el ateniense» ${ }^{63}$; pero también a Bion de Borístenes (ss. IV y III a. C.), de ordinario considerado inventor de la diatriba ${ }^{64}$, y a Fénix de Colofón y Cércidas de Megalópolis ${ }^{65}$ (s. III a. C.), con sus coliambos y meliambos moralizantes al estilo de Hiponacte.

De cuña griega es, asimismo, una segunda línea que, junto al character Lucilianus, se desprende de la antigua satura de Ennio: la sátira menipea. Su nombre deriva de las Saturae Menippeae de Varrón (s. I a. C.) — donde por primera vez figura, en un contexto literario, el sustantivo satura-, si bien no será empleado genéricamente hasta 1581, cuando Justo Lipsio escriba su Satyra Menippea, seguida, poco más tarde, por la francesa Satyre ménippé66. En 1605, Casaubon aún prefiere el binomio sátira Varroniana ${ }^{67}$, si bien reconoce, de manera más amplia, el genérico Menippea para designar una tradición a la que, tras Varrón, agrega a Séneca y Petronio, en el primer siglo de nuestra era, a Luciano en el segundo y a Marciano Capella en el quinto, todos ellos imitadores del cínico Menipo de Gadara, autor del siglo III a. C. de cuyos libros, escritos en una mezcla de prosa y verso, se conservan escasos fragmentos ${ }^{68}$.

57 Véase G. Highet, op. cit., págs. 35-37.

58 Véase Satirae, I 4, vv. 1-8.

${ }^{59}$ Cf. «Sátiros», en Diccionario de mitología universal (trad. de V. Villacampa), Planeta, México, 1992, pág. 217.

${ }^{60}$ Véase «Satire», en A. Preminger (ed.), The New Princeton Encyclopedia of Poetry and Poetics, Princeton University Press, Nueva Jersey, 1993, pág. 1114.

${ }^{61}$ Véase J. Bayet, Literatura latina (trad. de A. Espinosa), Ariel, Barcelona, 1975, pág. 113. También a Hiponacte se le atribuyen poderes mágicos, como el de maldecir, con resultados inciertos, a dos escultores que lo representaron exagerado en sus deformidades. Véase R. C. Elliott, op. cit., pág. 13.

${ }^{62}$ Simon \& Schuster, Nueva York, 1945, págs. 38-41.

${ }^{63}$ L. Guilhamet, «Socrates and Post-Socratic Satire», Journal of the History of Ideas, 46, 1, 1985, pág. 5. La traducción es mía.

${ }^{64}$ Apud C. W. Mendell, «Satire as Popular Philosophy», Classical Philology, 15, 2, 1920, pág. 153.

${ }^{65}$ Véase G. Hendrickson, «Satura Tota Nostra Est», pág. 51.

${ }^{66}$ Véase J. C. Relihan, Ancient Menippean Satire, John Hopkins University Press, Baltimore, 1993, pág. 12.

${ }^{67}$ Op. cit., II 2, págs. 201-11.

${ }^{68}$ De ahí que, como asienta en el siglo II Aulo Gelio (II 18, 6; XIII 31, 1), las de Varrón fueran llamadas sátiras cínicas. Según varios autores, la escuela cínica toma su nombre del vocablo $\kappa v ́ \omega v$, «perro», apelativo que Antístenes y Diógenes habrían adoptado para su frugal estilo de 
De los trece títulos que enlista Diógenes Laercio (s. III) en su Vida de Menipo $^{69}$, hoy día sólo los primeros se atribuyen con certeza al de Gadara ${ }^{70}$. Entre ellos destacan En la tierra de los muertos (NÉkvı), los Testamentos

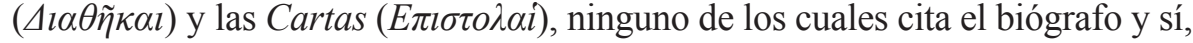
cosa extraña, otros que no incluye en la lista, como la Subasta de Diógenes

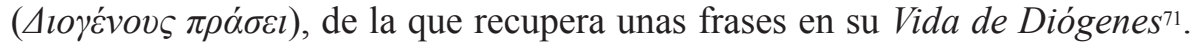
Entre los títulos que cita Ateneo sobresalen el Simposio ( $\Sigma \nu \mu \pi o ́ \sigma ı o v)$, probablemente una parodia análoga a los Deipnosofistas ${ }^{72}$, y el Arcecilao $(A \rho \chi \varepsilon \sigma i \lambda \alpha ́ \omega)^{73}$. Sin embargo, como anota Casaubon ${ }^{74}$, ni Laercio ni Ateneo hacen mención alguna a la sátira y, en cambio, el segundo denomina gracias (X́́ $\rho \imath \tau \varepsilon s)^{75}$ las obras del género cultivado por Meleagro ${ }^{76}$ (ss. II y I a. C.), coetáneo y continuador de Menipo ${ }^{77}$. Curiosamente, a pesar de hacerlo personaje central de sus propias historias, una de las citas más representativas de Menipo la pone Luciano en boca de Diógenes el cínico, que al comienzo de los Diálogos de los muertos, en un mensaje mediante el que invita al propio Menipo a viajar al mundo de los muertos, contrasta la auténtica risa que se experimenta en el Hades con el reír de los vivos, contenido por la duda y «por aquello tan repe-

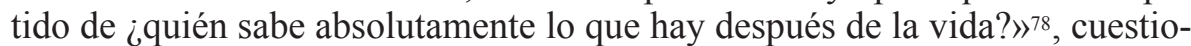
namiento que, sobra aclarar, heredarán sus epígonos.

El primero de ellos, Varrón, de cuya obra satírica, de la que elogia más la ciencia que la elocuencia, dice Quintiliano que no se reducía a la variedad de versos, puesto que contenía gran erudición acerca de la antigüedad griega y latina ${ }^{79}$. Se trata, sin duda, de un asunto problemático, pues cosa contraria expresa, sobre Menipo, Diógenes Laercio ${ }^{80}$, para quien el depurado estilo literario del de Gadara chocaba con la dudosa autenticidad de su filosofía, postura que Cicerón comparte a propósito de Varrón, cuyos tópicos filosóficos encuentra

vida, si bien Diógenes Laercio asegura que proviene del Cinosargo, gimnasio en las cercanías de Atenas donde aquél habría impartido sus clases. Véase "Cínicos», en J. Ferrater Mora, Diccionario de filosofía, I, Ariel, Barcelona, 1999, págs. 558-559.

${ }^{69}$ VI 8, 99-101.

${ }^{70}$ Cf. J. C. Relihan, op. cit., pág. 40.

71 VI $2,29$.

${ }^{72} \mathrm{XIV}, 629 \mathrm{e}$

${ }^{73} \mathrm{XV}, 664 \mathrm{e}$.

${ }^{74}$ I. Casaubon, op. cit., pág. 206.

75 Como las tres Gracias de la mitología. Véanse Homero, Ilíada, vv. 270-76, y Hesíodo, Teogonía, v. 907.

${ }^{76}$ Véase IV, 157b.

${ }^{77}$ Cf. J. C. Relihan, op. cit., pág. 41.

${ }^{78}$ I, 1, en Luciano, Obras completas, I (trad. de C. Vidal), Sucesores de Hernando, Madrid, 1910, pág. 186. La atribución se halla en B. McCarthy, «Lucian and Menippus», Yale Classical Studies, 4, 1934, pág. 12.

${ }^{79}$ Op. cit., X 1, 95.

${ }^{80}$ VI $8,100$. 
inspiradores pero insuficientes para la instrucción ${ }^{81}$. Antes que dar cuenta de un defecto de su obra, para un clasicista como Relihan la observación pone sobre la mesa la innovación literaria del de Rieti quien, asegura, en más de un fragmento de sus sátiras figura como un erudito envuelto en dificultades a causa de su pedantería ${ }^{82}$, autoparodia que pondría de relieve el aspecto cómico del discurso enciclopédico y la imposibilidad de acceder a una instrucción definitiva $^{83}$. Para respaldar esta opinión no bastan, empero, los noventa títulos y menos de seiscientos fragmentos, la mayoría tratante de curiosidades léxicas y sintácticas, que se conservan de las Menippeae, contenidas originalmente en ciento cincuenta libros de géneros tan dispares como la diatriba, el simposio, el viaje fantástico y el descenso al inframundo ${ }^{84}$. La teoría de Relihan, quien considera la menipea una versión paródica de la sátira en hexámetros, se basa más bien en las repetidas ocasiones en que Gelio ${ }^{85}$ hace hincapié en el deprecio de Varrón por la banalidad y su tendencia a parodiar los discursos filosóficos imperantes. A fin de cuentas, dice el norteamericano, «el pedante es susceptible de ser criticado por fiarse demasiado de las abstracciones y por llevar una vida inconsistente con la teoría» ${ }^{86}$, crítica que, pese a hallarse también en la sátira luciliana ${ }^{87}$, servirá de paradigma a la menipea.

Con todo, la referencia más conflictiva a la satura se debe, en los albores de nuestra era, a Tito Livio ${ }^{88}$. Cuenta el historiador que, en ocasión de una peste ante la que se habían agotado los recursos, fueron instaurados en Roma, en 364 a. C., los primeros juegos escénicos (ludi scaenici), para los cuales se llevaron de Etruria bailarines profesionales (ludiones). Las solemnes danzas etruscas serían de inmediato imitadas por intérpretes aficionados (iuventus) que, en sus Fescennini ${ }^{89}$, improvisaron versos jocosos (iocularia) en armonía con la danza y la música. Pronto aparecieron actores profesionales (vernaculis artificibus) que, inspirados por los ister etruscos, se hicieron llamar histriones. Éstos habrían implementado las saturae, consistentes no ya en rudas improvisaciones

${ }^{81}$ Cf. Academica posteriora, I, 8-9.

${ }^{82}$ V. gr., Bimarcus, frags. 1-3; Manius, frags. 2, 5, en Saturarum Menippearum reliquiae (ed. A. Riese), Teubner, Lipsia, 1865, págs. 105-106, 157.

${ }^{83}$ Cf. op. cit., pág. 54.

${ }^{84}$ Cf. loc. cit., págs. 51-52.

${ }^{85} V$. gr., I 17, 4 y sigs.; XIII 11, 1 y sigs.; VI 16, 1 y sigs.

${ }^{86}$ Op. cit., pág. 52. La traducción es mía.

${ }^{87}$ Amén de proponer que la sátira constituye una expresión popular de la filosofía práctica, en oposición a la falsa erudición de los doctos, Mendell rastrea el probable contacto intelectual de Lucilio con Panaecio quien, por la vía del estoicismo, hubo de introducir a Roma la doctrina profesada por los cínicos. Cf. art. cit., págs. 140-141.

${ }_{88}$ Cf. VII 2, 4-12.

${ }^{89}$ Pese a que muchos coinciden en que el mote proviene de fascinus ( $\left.\varphi \alpha \lambda \lambda o ́ \varsigma\right)$, lo que haría de las Fescennini un correlato exacto de las $\varphi \alpha \lambda \lambda l \kappa \alpha ́$ griegas, apelando a una analogía con las Atellanae, provenientes de Atella, Wilhelm Teuffel-Schuabe lo deriva de Fescennium, nombre de una localidad etrusca. Véase G. Hendrickson, «The Dramatic Satura and the Old Comedy at Rome», The American Journal of Philology, 15, 1, págs. 5-6. 
sino en canciones expresamente compuestas para acompañar la música de la flauta,y habrían marcado precedente para que, introduciendo el argumento, Livio Andrónico compusiera las primeras obras estructuralmente unitarias (Atellanae). Finalmente, los aficionados se habrían tomado revancha, mofándose del nuevo estilo dramático y presentando sus exodia al término de las atelanas.

Por cuanto a la satura, el asunto resulta problemático porque, a decir de Hendrickson ${ }^{90}$, Livio estaría recurriendo a un término contemporáneo, del que no hay evidencia anterior a Ennio, para designar una fase primitiva del teatro romano cuyo máximo exponente fue Naevio (s. III a. C.) y a la que Horacio, inmediato predecesor de Livio, se refiere simplemente como una modalidad apertam in rabiem ${ }^{91}$. Afirma el filólogo que poeta e historiador hacen relación, cada cual, de una evolución en completa sincronía con las tres etapas que, según Aristóteles ${ }^{92}$, trazaron el desarrollo de la comedia griega; esto es:

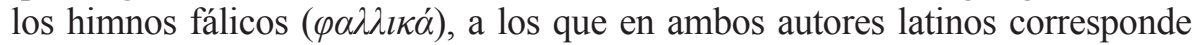

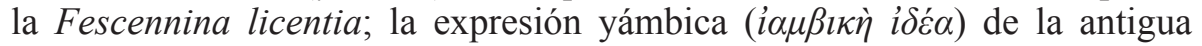
comedia ática, paralela a la aperta rabies de Horacio y la satura de Tito Livio, y finalmente la comedia nueva, dotada de $\mu \tilde{v} \theta o l$, «argumento», y orientada a deleitar al público y no ya a atacar a terceros ${ }^{93}$. Tampoco Ullman cree que satura se empleara originalmente para designar los espectáculos de los histriones, aunque disiente del paralelismo que su colega observa entre éstos y la comedia ática, toda vez que, como anota el propio historiador romano, las canciones de los profesionales se distinguían de las iocularia en que no necesariamente poseían un carácter cómico o polémico, constituyendo más bien un espectáculo de variedades, de donde el empleo de satura, «miscelánea», en oposición a la posterior fábula unitaria de Livio Andrónico94. Para Henning Webb, sin embargo, lo que resulta poco probable es que, siendo evidente que etimologiza la terminología de cada una de las fases que menciona, el historiador haya decidido hacer una excepción en el caso de los histriones, refiriéndose a sus espectáculos con un término de acuñación reciente y no con su nombre original95.

\section{Los siglos de la confusión}

En contraste con el riquísimo corpus satírico de la edad media, las teorías sobre la sátira no abundan en el periodo, defecto que, no es un secreto, se extiende

${ }^{90}$ Cf. Loc. cit., págs. 4, 21.

${ }_{91}$ Véase Epistolae, II 1, v. 145 y sigs.

${ }_{92}$ Véase Poética, 1449a, 5-15; 1449b, 6-9.

${ }_{93}$ Cf. «The Dramatic Satura and the Old Comedy at Rome», pág. 25. Una relación semejante a las de Horacio y Tito Livio se hallará más tarde en un autor del siglo IV como Evancio. Véase loc. cit., págs. 14-20.

${ }^{94}$ Cf. «Dramatic Satura», Classical Philology, 9, 1, 1914, pág. 11 y sigs.

${ }^{95} \mathrm{Cf}$. art. cit., pág. 182 y sigs. 
prácticamente a toda la literatura producida durante más de un milenio. Tal vez se deba a que, como asegura Sanford Shepard, el espíritu medieval sospecha de la literatura, desconfianza que «no es solamente una reacción contra las creencias del mundo antiguo, sino un profundo desasosiego frente a todo lo ficticio» ${ }^{96}$. De ser así, está claro que Diomedes pertenece todavía a la antigüedad tardía, de ahí que su definición de la sátira como obra que maldice de los vicios humanos aún recurra a la vieja relación establecida entre Lucilio y los comediógrafos griegos ${ }^{97}$. Y, sin embargo, tanto ésta como su aristotélica división de la poesía en tres géneros, a saber: activum vel imitativum, con intervención de los personajes pero no del poeta, ennarrativum, con la sola intervención del poeta, y commune vel mixtum, en la que participan tanto el poeta como los personajes ${ }^{98}$, pasarán a la edad media enrarecidas por la dudosa interpretación de San Isidoro (ss. VI y VII). El sevillano no deja de anotar cada una de las etimologías a las que Diomedes se refiere a propósito de la satura literaria ${ }^{99}$, pero al mismo tiempo demuestra una total incomprensión del género activo, en el que éste contempla el drama en sus tres variantes (tragedia, comedia y drama satírico), el mimo y los poemas dialogados, pues agrega a sus dominios a Horacio, Persio y Juvenal como representantes de una nueva clase de comedia que, dedicada a reprender los vicios, descendería directamente de la de Plauto y Terencio ${ }^{100}$. No cabe duda de que el satirici y el saturici que emplea Isidoro para referirse a Horacio y compañía están contaminados del Satiri que, en el listado de Diomedes, va precedido de tragica y comica, lo que probablemente se debe a que, a la regularización, en el siglo III, del adjetivo satiricus para calificar al autor de sátiras ${ }^{101}$, siguió un proceso inverso con el adjetivo Satyrica, del que Casaubon reprocha a Donato (s. IV) la acuñación del sustantivo satyra ${ }^{102}$, neologismo que, tal como hace Ausonio con el adjetivo satirica $^{103}$, el gramático empata ya con lo ridículo ${ }^{104}$.

${ }^{96}$ El Pinciano y las teorías literarias del Siglo de Oro, Gredos, Madrid, 1970, pág. 11.

${ }^{97}$ Cf. op. cit., III, pág. 485.

${ }^{98}$ Cf. loc. cit., págs. 482-83. En cuanto al modo de la imitación, lo cierto es que Aristóteles distingue sólo el dramático y el narrativo (véase Poética, 1448a, 18-24), pero no niega la posibilidad de que aparezcan juntos.

99 Véase Originum sive etymologicarum, v, 16; XI 3, 21; XX 2, 8.

${ }^{100}$ Cf. loc. cit., vIII 7, 7-9.

${ }^{101}$ Ap. U. Knoche, Roman Satire, Indiana University Press, Bloomington, 1975, pág. 3.

102 Véase op. cit., I 1, pág. 23.

103 Véase E. Curtius, op. cit., II, pág. 597. De acuerdo con Van Rooy (op. cit., pág. 194), más que recoger lo expresado por algún preceptista de la antigüedad tardía, la teoría de San Isidoro representa el clímax de la asimilación de la sátira a la comedia con que dio inicio la edad media, formando parte integral de la romanización mediante la que el obispo hispalense equipara a los primeros comediógrafos latinos, de los que poco sabía, con los autores de la vieja comedia ática, en cuyo caso su ignorancia era casi total.

${ }^{104}$ En efecto, en sus Comentarios a Terencio (Ev., II 5-6), Donato sitúa la satyra como intermediaria de la vieja y la nueva comedia, tanto en sentido histórico como literario. 
Ahora bien, si la contaminación resultante del contacto de satura y Satyrica se hubiera resumido, como en Diomedes, incluso como hoy día, a la semejanza que, sin apuros, se observa entre los sátiros del drama griego y los autores de la sátira romana, la cuestión no habría pasado a mayores. Lo grave es que la interferencia acompaña un total desconocimiento, por parte de los autores medievales, de las cualidades que hacen de un poema una obra dramática, una completa ignorancia del carácter escénico de la representación dramática que habrá de llegar al Dante, cuya Comedia llevará tal título no porque sus personajes actúen sin la intervención del poeta, sino por tratarse de una obra en estilo llano que comienza narrando hechos lamentables para acabar de modo afortunado ${ }^{105}$. Condicionados, en suma, por una radical simplificación de Diomedes, los autores del medievo se dieron a creer en una clasificación de la poesía en tres géneros: tragedia, comedia y sátira. La restricción pasa, con ciertas modificaciones, por autores latinos del siglo XII como Mathieu de Vendome, cuya tendencia maniquea lo lleva a incorporar la elegía, opuesta a la sátira tal como la tragedia se opone a la comedia ${ }^{106}$, y John of Garland, quien por primera vez separa el modo de la imitación (dramático, narrativo o mixto) de su contenido, que tocaría a lo cómico, lo trágico, lo satírico y lo elegíaco ${ }^{107}$, para llegar al prerrenacimiento español por la vía de Enrique de Villena, que califica su versión de Los doze trabajos de Hércules, de 1417, más de sátira que de tragedia ${ }^{108}$. Así, en la dedicatoria que precede a la Comedieta de Ponza, de 1436, dirá el Marqués de Santillana: «satira es aquella manera de fablar que tuuo vn poeta que se llamó Sátiro, el cual rreprehendió muy mucho los vicios e loó las vyrtudes» ${ }^{109}$.

Ello, aun cuando, ya en el siglo v, Marciano Capella había hecho figurar a la sátira como personaje y fuente de su De nuptiis philologiae et Mercurii. Es Satura quien, a través de un redactor incompetente (el propio Capella), relata la ascensión de Filología - falsamente etimologizada como devota de los oráculos caldeos ${ }^{110}$ - en aras, a la postre frustradas, de contraer nupcias con Mercurio. Pero, ojo, es ella quien se enfrasca en una polémica con su escribano acerca de la naturaleza misma de la obra, de la evidente desproporción entre su estilo y su temática, de la conveniencia de contar la verdad mediante

${ }^{105}$ Cf. G. Highet, La tradición clásica, I (trad. de A. Alatorre), Fondo de Cultura Económica, México, 1954, págs. 118-120.

${ }^{106}$ Cf. M. de Vendome, Ars versificatoria, Libraire Catholique, París y Bruselas, 1879, págs. 46-47.

${ }^{107}$ Cf. Poetria, en É. de Bruyne, Estudios de estética medieval, I, Gredos, Madrid, 1958, págs. 24-29, y en F. López Estrada, Introducción a la literatura medieval española, Gredos, Madrid, 1987, pág. 205.

108 E. de Villena, «Carta a Mosén Pere Pardo», en Obras completas, I, Turner, Madrid, 1994, pág. 6

109 Í. López de Mendoza, Marqués de Santillana, «Carta a doña Violante de Prades», en M. P. A. M. Kerkhof (ed.), Comedieta de ponça. Sonetos, Cátedra, Madrid, 1986, pág. 168.

110 Véase II 142, 36g. 
historias de ficción ${ }^{111}, \mathrm{y}$ ella quien concluye con un lamento al ver sus expectativas defraudadas no ya por el poeta, por ella misma y su incapacidad para dar sentido a su expresión y acceder a la gran filosofía ${ }^{112}$. La caracterización se ciñe, claro, a la tradición menipea ${ }^{113}$, a la que el De nuptiis se suma, como exponente latino tardío, junto con las Mitologías de Fulgencio ${ }^{114}$ (s. v) y la Consolación de la filosofia, de Boecio (ss. V y VI), aunque no deja de sorprender la escasa influencia que habría de tener en los autores que, en siglos posteriores, se ocuparon de la sátira, con todo y que, en lo que toca a las artes liberales, la obra del africano sirvió de norma a toda la edad media'115.

A cambio, su peso se nota en la variedad formal que caracteriza la literatura satírica del medievo y en la proliferación, hacia el cambio de milenio, de textos como el Tractaus Garciae, de 1099, en el que, tras un viaje a la curia papal en Roma, un canónigo toledano dirige su prosa, mediante recursos estilísticos hiperbólicos o netamente paródicos, contra la avaricia de los dignatarios clericales, tal como había hecho ya, en verso, el narrador del Apocalypsis Goliae ${ }^{116}$. Un siglo después, en la prosa de su De nugis curialium, Walter Map empleará recursos análogos para defender al clero secular frente a las órdenes monásticas, y Rutebeuf legará en los versos de su Roman de Carité una de las primeras sátiras vernáculas que se conocen ${ }^{117}$. Y si bien en el periodo predomina la materia eclesiástica, se hallan asimismo sátiras mundanas, como el Speculum stultorum, de 1180, donde Nigel Longchamp narra en verso las aventuras de un asno en busca de una cola más larga ${ }^{118}$, o el poema inglés del siglo XIV que recoge Thomas Wright y que da cuenta de la avaricia en todos los escaños de la sociedad ${ }^{119}$. El XIV es también el siglo de la prosa y los versos castellanos de don Juan Manuel y del Arcipreste de Hita, a quienes seguirán Boccaccio en Italia y Chaucer en Inglaterra y, un siglo más tarde, Villon en Francia' ${ }^{120}$.

111 Véanse III, 221-222, 48-49g; VI, 576-79, 189-90g; VIII, 808-809, 272-273g.

${ }^{112}$ Cf. IX, 999-1000, 336g.

${ }^{113}$ Cf. loc. cit., 997-998, 335-36g. En su vocación de enseñar las virtuosas disciplinas griegas, la historia dictada por Satura comprende, así, un revoltijo en el que, además del verso y la prosa, se dan cita lo culto y lo vulgar, lo trivial y lo inefable, las musas, los dioses, los filósofos...

114 Donde, por cierto, aparece Satyra como personaje. Véase J. C. Relihan, op. cit., págs. $152-163$

${ }^{115}$ Cf. E. Curtius, Literatura europea y Edad Media latina, I (trad. de M. Frenk y A. Alatorre), Fondo de Cultura Económica, México, 1955, pág. 63 y sigs. Llamadas así por tratarse de disciplinas no lucrativas, las artes liberales se agrupan en trivium: gramática, retórica y dialéctica, y quadrivium: aritmética, geometría, música y astronomía. El nombre del primer grupo data del siglo IX; el del segundo se debe a Boecio.

116 Cf. L. Kendrick, «Medieval Satire», en R. Quintero (ed.), A Companion to Satire, Blackwell, Malden, Oxford y Carlton, 2007, págs. 54-57.

${ }^{117}$ Cf. loc. cit., págs. 61-65.

${ }_{118}$ Cf. loc. cit., págs. 58-61.

${ }^{119} \mathrm{Cf}$. The Political Songs of England, from the Reign of John to that of Edward II, Camden Society, Londres, 1839, págs. 323-345.

${ }^{120}$ En lo tocante a la tradición ejemplar de la que forman parte los primeros cuatro, nótese el peso que ejercieron los relatos de Las mil y una noches y otras colecciones orientales sobre 
Y aunque poco se sabe de la sátira castellana antes del trecento, misma que habrá de florecer un siglo después con la mira puesta en políticos, conversos y semitas, Kenneth Scholberg documenta la proliferación de tópicos satíricos en las poesías catalana de los siglos XII y XIII y galaicoportuguesa del XIII y el XIV121.

\section{Y se hizo la luz}

El siglo XVI estará marcado por el reingreso de las teorías aristotélicas al panorama filosófico-literario de occidente $\mathrm{y}$, en consecuencia, por una nueva división de los géneros poéticos en épico, lírico y dramático. La diferencia de este último respecto al género activo de la edad media estriba en que, tanto Giambattista Giraldi en sus Discorsi de 1554 como, cinco años después, Antonio Minturno en su Poetica, comprenden ya su carácter escénico ${ }^{122}$. Replican ambos, no obstante, el malentendido de Francesco Robortello, quien

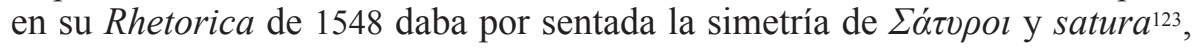
por lo que su propuesta de integrar la sátira al género escénico implica una rotunda falta de discriminación entre ésta y el drama satírico. De hecho, Giraldi define la sátira como una modalidad escénica que combina elementos de tragedia y comedia ${ }^{124}$. En 1589, el inglés George Puttenham propondrá, a cambio, una genealogía que parte de la sátira, que habría consistido en un canto quejoso, pasa por la vieja comedia, maledicente como su antecesora pero con una estructura más dramática, y desemboca en la comedia nueva, donde la reprehensión se vuelve anónima y sutil 125 .

el espíritu satírico de la baja edad media y el prerrenacimiento (cf. E. Anderson Imbert, «El cuento español», en Estudios sobre letras hispánicas, Libros de México, 1974, pág. 259). Cabe, asimismo, considerar como antecedente los cuentos milesios que cultivó Arístides en el siglo II a. C. y que prefiguran algunos de los episodios intercalados del Satiricón de Petronio, el Asno de oro de Apuleyo y aun del Quijote. Véase R. Heredia Correa, De Petronio, el Satiricón y algunas digresiones, Universidad Nacional Autónoma de México, 1996, pág. 26.

${ }^{121}$ Cf. K. Scholberg, Sátira e invectiva en la España medieval, Gredos, Madrid, 1971, págs. 15-49, 62-99.

${ }_{122}$ Cf. B. Weinberg, A History of Literary Criticism in the Italian Renaissance, I, Chicago University Press, 1961, págs. 387-388, 392, 742.

123 Véase loc. cit., pág. 400 y sigs.

${ }^{124}$ Cf. loc. cit., págs. 443-444

125 Cf. Ó. J. Campbell, Comicall Satyre and Shakespeare's Troilus and Cressida, Huntington, San Marino, 1970, págs. 28-29. Nótese la semejanza con Donato, donde la sátira provee el enlace entre la vieja y la nueva comedia (véase supra, n. 102). De hecho, la idea de que el drama satírico antecede a la comedia nueva sedujo a muchos preceptistas del renacimiento, entre los que, en nuestras letras, se cuentan el Pinciano, quien la repite en su Philosophía antigua poética, de 1596, y Luis Alfonso de Carvallo, quien hace lo propio en su Cisne de Apolo, de 1602. Véase A. Pérez Lasheras, Fustigat mores. Hacia el concepto de la sátira en el siglo XVII, Universidad de Zaragoza, 1994, págs. 71-75. 
Si bien, ya en 1580, Fernando de Herrera ${ }^{126}$ juzgaba anómala la postura de Escalígero, empeñado, aún en 1561, en derivar la sátira de aquellos seres mitad hombres mitad cabras ${ }^{127}$, fue Casaubon, insisto, quien al albear el siglo XVII se ocupó de despejar la añeja confusión. De tales criaturas dice el erudito ${ }^{128}, y$ para ello recurre a Estrabón y a Macrobio, que se integraron a la corte de Baco de manera tardía, pues no se hace mención de ellas en el Himno a Dionisios atribuido a Homero en el que, en cambio, son las ninfas quienes alimentan al dios ${ }^{129}$. Tras referirse brevemente a Eurípides, en el segundo capítulo de su tratado, sin duda uno de los más interesantes del primer libro, el suizo da cuenta de la asimilación de sátiros, silenos y, posteriormente, faunos y, haciendo gala de gran erudición, revisa su paso por las Metamorfosis ${ }^{130}$, donde Ovidio (ss. I a. C. y I) narra el martirio y la transformación de Marsias tras haber sido derrotado por Apolo en el tañir de la flauta, por Plinio ${ }^{131}$ (s. I), quien plantea la relación de los sátiros con los egipanes, criaturas caprinas provenientes, dice el geógrafo, de Etiopía ${ }^{132}$, y por Eliano (ss. II y III), que en sus Variae historiae da cuenta de la captura de Sileno por parte de Midas ${ }^{133}$, para terminar con una disertación en la que, entre otros tópicos, menciona el probable parentesco de sátiros y centauros, el hipotético origen hebraico de aquéllos, la semejanza planteada por Alcibíades entre Sócrates y Marsias en el Banquete de Platón ${ }^{134}$, e incluso la relación, observada por Hipócrates y Galeno, entre el carácter itifálico de los sátiros y un padecimiento como el priapismo ${ }^{135}$. El capítulo siguiente, también de gran trascendencia, se ocupa ya del drama satírico. Ahí el humanista se enfrasca en una discusión con Aristóteles y Diomedes en cuanto a los géneros dramáticos, de la que concluye que el drama satírico se sitúa genealógicamente entre la tragedia y la comedia, y luego pasa revista a las semejanzas de aquél con cada una de éstas para definir el drama satírico como un:

[...] poema dramático, anexo a la tragedia, en el que aparece un coro de sátiros junto a personajes ilustres que realizan acciones notables, en

${ }^{126}$ Obras de Garcilaso de la Vega con anotaciones de Fernando de Herrera (prólogo de A. Gallego Morell), Consejo Superior de Investigaciones Científicas, Madrid, 1973, pág. 358.

${ }_{127}$ Véase $o p$. cit., I 12.

${ }^{128}$ Cf. op. cit., I 2, págs. 26-29

129 Véase Himnos homéricos, XXVI.

130 Véase VI, vv. 382-400.

${ }^{131}$ Cf. Naturalis historia, v 8; VI 30.

${ }_{132}$ Éstos habrían nacido de la ninfa Egea y Pan, dios de la fertilidad, de probable origen arcadio, al que se representa con las extremidades inferiores de cabra, lo mismo que los cuernos, orejas y cola. Véanse «Egipanes», en G. Sechi Mestica, Diccionario de mitología universal, (rad. de M.-P. Bouyssou y M. V. García), Akal, Madrid, 2007, pág. 83, y «Pan», en Á. M. Garibay, Mitología griega, Porrúa, México, 1986, págs. 190-191.

133 III 28.

134 215a-19d.

${ }^{135}$ Cf. I. Casaubon, op. cit., I 2, págs. 29-68. 
parte serias y en parte jocosas, escrito en un estilo hilarante y con un final regularmente alegre ${ }^{136}$.

Pese a insistir en la confusión etimológica, al comienzo del segundo libro, Casaubon propone un origen de la satura que de algún modo evoca al del drama satírico, ya que tiende un puente, sin sugerir, nótese, nexo etimológico alguno, entre las Fescennini, que en Tito Livio anteceden a las saturae, y los mordaces versos saturnios que, asegura Ennio ${ }^{137}$, cantaban los faunos y de los que, hallando ejemplos en Naevio, dicen Atilio Fortunaciano (c. s. IV) que no observaban una métrica estricta y Diomedes ${ }^{138}$, que agregaban una sílaba al yambo ${ }^{139}$. Los capítulos segundo y tercero se ocupan, respectivamente, de la tradición menipea de Varrón y del modelo de Lucilio, que el erudito encuentra en notable concordancia con los silos; cita, en este sentido, a Diógenes Laercio $^{140}$, quien dice de Xenófanes (s. VI y V a. C.) que incorporaba al hexámetro no sólo versos heroicos y yámbicos, como Lucilio, sino también elegíacos ${ }^{141}$. Finalmente, tras iniciar con un recuento, apoyado en Diomedes y Mario Victorino ${ }^{142}$ (s. IV), de las semejanzas entre el drama satírico griego y las atelanas de Livio Andrónico, precursoras de la comedia latina ${ }^{143}$, el capítulo cuarto subraya el sentido «miscelánea» que se desprende de las probables etimologías de satura, con el objeto de definir la sátira como un «escrito, mezcla de prosa y verso, susceptible de tratar variados argumentos» $\rangle^{144}$.

No obstante, pese a la rapidez con que viajaban las ideas en la Europa de los siglos XVI y XVII, las ideas de Casaubon tardarían en arraigar. Todavía en 1611, Covarrubias se referirá a la sátira como un «género de verso picante, el cual reprehende los vicios y desórdenes de los hombres» ${ }^{145}$ y al satírico como aquel que «escribe sátiras o tiene costumbre de decir mal» $»^{146}$. Este parentesco con la maledicencia conducirá, durante el siglo XVII, la concepción de la sátira por una doble vía. Será, por una parte, condenado por los preceptistas, así el

${ }^{136}$ Loc. cit., pág. 100. La traducción y las cursivas son mías.

137 Véase Annalium, VII 1, 221-222, en J. Vahlen (ed.), op. cit., pág. 34.

138 Véase III, en H. Keil (ed.), op. cit., pág. 512.

${ }^{139}$ Cf. I. Casaubon, op. cit., II 1, pág. 177 y sigs.

${ }^{140}$ IX 2, 18.

${ }^{141}$ I. Casaubon, op. cit., II 3, pág. 223.

142 Véanse, respectivamente, III, en H. Keil (ed.), op. cit., págs. 482, 490, y Ars grammatica, II 4, 8-25; III 12, 1-15, en H. Keil (ed.), Grammatici latini, vi, Teubner, Lipsia, 1874, págs. 81-82, 135.

143 Véase P. Frassinetti (ed.), Fabularum Atellanarum fragmenta, Paravia, Turín, 1955, y también W. Beare, «Plautus and the Fabula Atellana», The Classical Review, 44, 5, 1930, págs. 165-168, y J. Trapido, «The Atellan Plays», Educational Theatre Journal, 18, 4, 1966, págs. 381-390.

144 I. Casaubon, op. cit., pág. 258.

145 Se suman a su definición unas líneas en latín que, valga la expresión, confunden per saturam las etimologías de Diomedes.

146 Cf. «Sátira»y «Satírico», en Tesoro de la lengua castellana o española, Castalia, Madrid, 1995, pág. 886. Mías las cursivas. 
español Francisco de Cascales, quien en sus Tablas poéticas de 1617 lo atribuirá a los antiguos griegos y querrá borrarlo de la nueva sátira de cuña latina, con su «dezir propio y puro, y en las sentencias, la agudeza» ${ }^{147}$, mientras que, por la otra, se hará presente en gran parte de la poesía satírica de la época, y para muestra basten, en nuestro siglo de oro, los botones de Góngora y Quevedo ${ }^{148}$.

Más que por su definición de la sátira como «imitación de una viciosa y vituperable acción, con versos puros y desnudos, para enmendar la vida» ${ }^{149}$, Cascales se distingue por ser el primero en combinar la división tripartita de la poesía de un Minturno con la exclusión de la sátira del género escénico propuesta por Carvallo ${ }^{150}$. Para el murciano, la sátira constituye una especie menor de la épica. De su carácter narrativo, explica, deviene el rodeo que, mediante figuras reductivas como el símil, la hipérbole, la antonomasia y la ironía, distingue la nueva sátira de la antigua invectiva griega; ello, ojo, sin desatender las cualidades escénicas de semejante recurso, dado a la incorporación de máscaras tras las que se oculta el poeta ${ }^{151}$. En adelante, el XVII será el siglo del deslinde entre sátira y géneros dramáticos. En su estudio sobre el paso del concepto por la época, Pérez Lasheras identifica este impulso en un autor como Nicolas Boileau, por lo demás, adalid de la sátira gala del periodo, quien en su Arte poética de 1674 la incluye entre los géneros menores, junto con la pastoral, la elegía, la oda y el epigrama, y en consideración de la tragedia, la comedia y la épica como géneros mayores ${ }^{152}$.

En este tenor, la discusión llegará, en 1693, al primer gran tratado vernáculo sobre el tema. Me refiero, claro, al Discourse Concerning the Original and Progress of Satire, de John Dryden. Como Casaubon, Dryden se referirá a

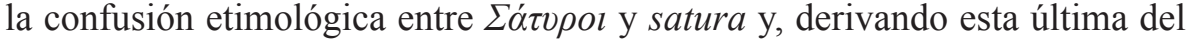
adjetivo satur ${ }^{153}$, dará cuenta del relato de Tito Livio a propósito de la satura

${ }^{147}$ Espasa-Calpe, Madrid, 1975, pág. 183. Citado en A. Pérez Lasheras, op. cit., pág. 79. Aun así, hacia el final de su primera sátira (vv. 101-107), Horacio replica a un interlocutor imaginario: «non ego avarum cum veto te, fieri vappam iubeo ac nebulonem: est inter Tanain quiddam socerumque Viselli» («Si te prohíbo que seas avaro no es para que seas libertino ni disipador. Entre Tanais y el suegro de Viselio hay un término medio»: Sátiras, ed. bil. de F. Montes de Oca, Universidad Nacional Autónoma de México, 1961, pág. 5).

148 Alvin Kernan da seguimiento a la satanización del autor de sátiras durante la época isabelina, para la que «el efectivo ataque contra el vicio delinea inevitablemente una personalidad pesarosa e inconsistente»: The Cankered Muse: Satire of the English Renaissance, Archon, Hamden, 1976, pág. 158 (mía la traducción).

149 Op. cit., pág. 180.

${ }^{150}$ Apud A. Pérez Lasheras, op. cit., pág. 74.

${ }^{151}$ Cf. loc. cit., págs. 79, 81.

152 Cf. loc. cit., pág. 96.

153 «For satira - explica - is not properly a substantive, but an adjective; to which the word lanx (in English, a charger, or large platter) is understood; so that the Greek poem, made according to the manners of a Satyr, and expressing his qualities, must properly be called satyrical, and not Satire» (J. Dryden, Essays of John Dryden, II, Oxford University Press, 1900, pág. 45). 
dramática para luego pasar revista a la tradición latina heredera de Ennio ${ }^{154}$. También él, como el suizo, se detendrá en Persio (s. I), pero a diferencia de su maestro, lo hará para quejarse del hermetismo de sus sátiras y, a cambio, defender la claridad de Horacio y Juvenal ${ }^{155}$. Y también él, como Cascales, concebirá la sátira como subespecie de la épica, elogiando la agudeza del discurso indirecto y denostando la invectiva desnuda, pero en cambio incluirá asimismo la tragedia en la categoría de la poesía heroica, misma que, dice, emana de:

[...] some extraordinary undertaking which requires the strength and vigour of the body, the duty of a soldier, the capacity and prudence of a general, and, in short, as much, or more, of the active virtue, than the suffering ${ }^{156}$.

De acuerdo con el británico, ahí donde Horacio tuvo éxito puliendo la comicidad de la sátira luciliana, Juvenal perfeccionó el género al poner de manifiesto su faceta trágica mediante la sustitución de la risa por la reformación del pecado ${ }^{157}$. Movido por esta diferencia, Dryden se ajusta a la definición de Daniel Heinsius, para quien la sátira constituye una:

[...] clase de poema, carente de acciones en serie, cuya función expiatoria reprehende severamente los vicios y la ignorancia y en cuyo estilo, parcialmente dramático, parcialmente simple, o bien una mezcla de ambos, confluyen familiarmente el discurso agudo y pungente y la versatilidad cívica de la broma con el objeto de suscitar o bien el rencor, o bien la risa o bien la indignación del lector ${ }^{158}$.

154 Véase loc. cit., págs. 55-67.

155 Véase loc. cit., págs. 70-75. «I am pleased with both — dice-; but I owe more to Horace for my instruction, and more to Juvenal for my pleasure» (loc. cit., pág. 82). Con semejante aserción, Dryden se aparta anticipadamente de la polaridad radical que autores posteriores plantearán entre la sátira horaciana y la de Juvenal (v. gr., F. Montes de Oca, «Introducción» a Horacio, Sátiras, pág. LXXVIII, L. Feinberg, Introduction to Satire, Iowa State University Press, Ames, 1967, pág. 4, y K. Scholberg, op. cit., pág. 11), misma que, en contraste con la sutil confidencia de aquélla, se inclinaría por la indignación y la crítica directa. Cierto que Horacio resulta más gracioso y amigable, cuando que Juvenal cuenta con un estilo agrio hasta lo soez, pero también que, para exponer tópicos comunes, ambos recurren a una misma clase de procedimientos, entre los que destaca el que Zoja Pavlovskis-Petit denomina «circularidad irónica» (véase «Irony and Satire», en R. Quintero, ed., op. cit., págs. 513-515) y que se manifiesta como autodesprecio en Horacio y, en su homólogo, como inversión retórica.

${ }^{156}$ J. Dryden, op. cit., pág. 31.

${ }^{157}$ Cf. loc. cit., págs. 91 y 96. Medio siglo más tarde, en ocasión de la muerte de Pope, Walter Harte agregará a este tema una valiosa distinción al señalar que la risa resulta adecuada para satirizar la estupidez, pero difícilmente para corregir el vicio. Cf. An Essay on Satire, Dodsley, Londres, 1745, pág. 20, v. 261 y sigs.

${ }^{158}$ Cf. loc. cit., pág. 100. Dryden traduce del De satyra Horatiana, de 1612, donde Heinsius promueve una idea de la sátira al margen de la comedia y en evidente conexión con la tragedia según la define Aristóteles (véase J. H. Meter, The Literary Theories of Daniel Heinsius, Van Gorcum, Assen, 1984, págs. 109 y 280), si bien resulta significativo que, a propósito de dicho 
Agrega a ello el inglés, y aquí difiere radicalmente de Casaubon, la exigencia de que el poema se centre en un solo tema que subordine, de haberlos, los tópicos secundarios, tal como las subtramas de una tragicomedia se incorporan a su argumento principal ${ }^{159}$.

Tendrá que pasar, no obstante, más de medio siglo para que un autor español se ocupe del tema a conciencia. Será el caso de Agustín de Montiano y sus Notas para el uso de la sátira (1758), de las que Edward Coughlin recoge una selección ejemplar ${ }^{160}$. Al margen de la defensa, en acuerdo con Dryden, de un tipo de sátira piadosa y cristiana, la definición del vallisoletano parece una de las más completas de la época, ya que concibe la sátira como:

[...] un discurso, alguna vez en prosa, y lo más común en verso, determinado a hacer ridículos y aborrecibles los vicios del entendimiento y de la voluntad con vivacidad picante, induciendo con la sal de las expresiones, y el alma de los conceptos al amor del saber y de la virtud ${ }^{161}$.

Dado que durante el renacimiento y el barroco la sátira gozó de muy buena salud, harían falta muchas páginas para dar cuenta del extenso catálogo de literatura satírica del periodo. La variante métrica la cultivaron principalmente los ingleses, entre ellos Milton, Donne y el propio Dryden, pero su furor se dejó sentir también en otras cortes, como la francesa, de la mano de Boileau, y la española, donde brillan, más que nadie, Góngora y Quevedo. Por cuanto a la prosa satírica, tuvo a su máximo representante en Erasmo, seguido de cerca por Moro en Inglaterra y, más tarde, por el irlandés Jonathan Swift. La tradición menipea, por su parte, adquiere inusitados bríos en Rabelais, si bien pasa prácticamente por todas las lenguas nacionales; ahí están Teofilo Folengo con su Maccheronee (1521), Quevedo con sus Sueños (1613), Burton con su Anatomía de la melancolía (1621) y el propio Swift con sus Viajes de Gulliver (1726). Ello, sin mencionar la picaresca anónima del Lazarillo de Tormes (1554), las de Quevedo, Alemán y Grimmelhausen, y desde luego, la literatura ejemplar y la fábula de animales que Cervantes cultivó tan bien, e incluso el diálogo satírico, cuyo máximo exponente fue, creo, el Aretino. Finalmente, aunque no por último, cabría sumar a los autores de ese género naciente, el vodevil, que tan buenos dividendos reportó al teatro de la época, en especial en Francia, donde fue acogido por los herederos de la comedia italiana.

nexo, el inglés sitúa a Juvenal por encima de Horacio, cuando que su tutor prefiere al segundo. Véase B. Becker-Cantarino, Daniel Heinsius, Twayne, Boston, 1978, pág. 152.

159 J. Dryden, op. cit., pág. 102.

160 Véase E. Coughlin, La teoría de la sátira en el siglo XVIII, Juan de la Cuesta, Newark, 2002, pág. 94 y sigs.

${ }^{161}$ Citado en loc. cit., pág. 38. 


\section{La era de las revoluciones}

Con la entrada de las monarquías constitucionales y las repúblicas democráticas, la sátira cobrará un nuevo matiz ligado a la política. Y no es que no existiera la sátira política con anterioridad, que ejemplos sobran de todas las épocas, sino que por primera vez los autores de sátiras adoptan la función de periodistas o, en el argot de hoy día, de líderes de opinión.

Se reconoce en Dryden al precursor de la nueva sátira política ${ }^{162}$, al menos en la lengua que, poco después, empleará Pope para desnudar a sus contemporáneos ${ }^{163}$, si bien la modalidad florece en toda Europa y aun en las jóvenes naciones americanas. Coughlin revisa la apología de la sátira que, a lo largo del siglo XVIII, propugnaron periódicos españoles como El Censor y el Memorial Literario, en el primero de los cuales publicó Melchor de Jovellanos, en 1786, su «Sátira primera a Arnesto», acompañada de una defensa de sus cualidades morales y didácticas ${ }^{164}$, mientras que un número de 1790 del segundo dice de un autor que «las costumbres, los usos, la literatura, el teatro todo es objeto de su sátira, que puede mirarse como una pintura de nuestro estado actual en los diversos ramos que comprende ${ }^{165}$. Dadas las condiciones políticas de la Europa dieciochesca, colapsadas tras la era de los descubrimientos, no es de extrañar que el lozano espíritu ilustrado dotara a la sátira de la ingeniosa mordacidad de un Nicolás Fernández de Moratín, de un Cadalso, en nada comparada, por lo demás, a la de Pope en Inglaterra. Distinto, si no único, será el caso de los Estados Unidos. Ahí, una vez conquistada la independencia, los autores de versos satíricos agregarán al viejo estilo punitivo el entusiasmo de quienes resguardan con orgullo su flamante república de los vicios del viejo mundo ${ }^{166}$. Al contrario de lo que pretendía Horacio con sus sermones, en Norteamérica la sátira se dirige al gran público, constituyéndose por primera vez como medio de expresión

auténticamente democrático; no en balde asegura, en 1818, el periodista Thomas Green Fessenden que «la existencia del gobierno republicano depende del conocimiento y la virtud de las masas, fuente de todo poder y salvaguarda de la libertad pública» ${ }^{167}$. Por su parte, la sátira política francesa se debate entre las

162 Apud A. Pérez Lasheras, op. cit., pág. 99.

163 «So proud - dice este último en uno de sus pasajes más famosos, extraído del epílogo a sus sátiras (vv. 205-209) - I am no Slave: So impudent, I owe myself no Knave: So odd, my Country's Ruin makes me grave. Yes, I am proud; I must be proud to see men not afraid of God, afraid of me»».

164 Véase E. Coughlin, op. cit., pág. 68.

${ }^{165}$ Citado en loc. cit., pág. 69.

${ }_{166}$ Hacia el cambio de siglo, en un poema satírico que es casi una profecía, el republicano Winthrop Sargent se refiere a su país como una «mina de riquezas» cuyos beneficiarios, haciendo honor a su solvencia, habrán de desarrollar su genio «Till we surpass the pride of Greece, and Romel And shine the model of each age to come». Citado en G. L. Roth, «American Theory of Satire, 1790-1820», American Literature, 29, 4, 1958, pág. 406.

${ }^{167}$ En loc. cit., pág. 407. La traducción es mía. 
garantías de la Revolución y el advenimiento sucesivo del imperio y la monarquía constitucional. En esta línea se halla, en 1820, la correspondencia dirigida por Paul-Louis Courier a un redactor del Censeur a propósito del duque de Decazes, funcionario tanto de Napoleón como de Luis XVIII 168.

Al margen de lo estrictamente político, el espíritu satírico del dieciocho se tiñe por doquier de la contradicción implícita que los ilustrados detectaron en la modernidad; esto es, la problemática confluencia del entusiasmo de la razón y el escepticismo de la intuición, del afán protréptico del progreso y la desilusión surgida de las desigualdades y la intolerancia. Se trata, claro, de un campo de cultivo ideal para la menipea; así lo atestiguan, entre otros, los ingleses Henry Fielding con sus Misceláneas (1743) y Lawrence Sterne con su Tristram Shandy (1767), los franceses Voltaire, con su Micromegas (1752) y su Cándido (1759), y Diderot con su Jacques el fatalista (1778), y aun un mexicano como Fernández de Lizardi con su Periquillo Sarniento (1816).

Por lo que hace a la teoría, suelen aún repetirse, no obstante, las propuestas de un Dryden y un Cascales. Únicamente los alemanes darán un paso adelante, y qué paso, al otorgar a la sátira un lugar preponderante en el marco del idealismo. En 1795, Friedrich Schiller se referirá al antagonismo de sátira e idilio como fuentes de la creación, pues si éste resulta de la completa identificación entre realidad e ideal, aquélla es producto de su total ruptura, donde «el mundo de lo existente se contrapone como cosa imperfecta al ideal ${ }^{169}$. Para ello, dice, el poeta se ve en la alternativa de proceder, o bien con pasión y seriedad, haciendo acopio de su voluntad para crear una sátira patética, o bien con ánimo plácido y jocoso, en cuyo caso domina el entendimiento y la resultante es una sátira festiva. Pese a que en ambas variantes la aversión a la realidad abreva de la contraposición del ideal, la sátira patética llevaría la delantera por su proximidad con lo sublime, mientras que la festiva se conformaría con el tratamiento estético de su objeto:

Si la emoción resulta del ideal contrapuesto a la realidad, en lo sublime de ese ideal se pierde todo sentimiento inhibitorio, y la grandeza de la idea que nos llena nos levanta por encima de todas las limitaciones de la experiencia ${ }^{170}$.

Y más adelante: «La sátira patética debe siempre brotar de un espíritu vivamente penetrado del ideal. Sólo si domina el anhelo de armonía, puede y debe nacer ese hondo sentimiento de contradicción moral y esa ardiente indignación

168 Véase C. Arnould, La satire, une histoire dans l'histoire, Presses Universitaires de France, París, 1996, págs. 108-109.

169 Sobre poesía ingenua y poesía sentimental (trad. de J. Probst y R. Lida), Verbum, Madrid, 1994, pág. 36. Un tercer tipo de relación entre la realidad y el ideal la constituye, según Schiller, la elegía, donde el contraste entre ambos, más que predisponer el ánimo a las ideas, arroja un sentimiento de pérdida con respecto a la naturaleza y de inaccesibilidad para con el ideal. Véase loc. cit., pág. 43.

${ }^{170}$ Loc. cit., pág. 36. 
contra la perversión $\rangle^{171}$, cualidades que observa en Rousseau y Haller, herederos ambos de Juvenal. La burlesca, en cambio, ha de provenir de un corazón bello $\mathrm{y}$, para contrarrestar la frivolidad de su objeto, debe ennoble-cerlo mediante el lenguaje indirecto, resignándose, por lo demás, a unos cuantos momentos de arrebato y sublimidad ${ }^{172}$.

En sus Lecciones de estética (1835), Hegel situará la fractura en el seno de la transición del arte clásico al arte romántico, el de mayor refinamiento, de acuerdo con él, en el desarrollo histórico que habría iniciado con la forma simbólica ${ }^{173}$. En tal progresión, la sátira resulta del choque del sujeto con la realidad, de la que se aparta malhumorado al cerrársele el acceso a las formas puras del arte y la poesía. Puesto que aspira a un bien situado fuera del arte, la sátira, para el alemán, nada tiene que ver con la épica o la lírica; de hecho, sólo aspira a lo poético en la medida en que la necedad de la que se hace enemiga se derrumba por sí misma ${ }^{174}$. Considerando el peso que ejerció el idealismo y las circunstancias de una época alborotada a un tiempo por la revolución del conocimiento y el despunte de la subjetividad, nada extraño resulta que, en el siglo XIX, la sátira haya sobrevolado los abismos de la incertidumbre y la especulación al modo de un Byron, de un Browning y un Kierkegaard o que, en el otro lado del espectro, se haya refinado hasta la bizarría de un Gogol, de un Balzac o un Pérez Galdós.

\section{La época contemporánea}

Las propuestas de los idealistas a propósito de la sátira tendrán eco tanto en los autores del diecinueve como en aquellos que se ocuparon del tema durante el siglo Xx. Las repetirá, sin variaciones esenciales, John Middleton Murry en 1922, agregando el imperativo de que el autor de sátiras oculte su emoción de manera que luzca imparcial en la medida de lo posible ${ }^{175}$. Sobre

${ }^{171}$ Loc. cit., pág. 37.

172 Loc. cit., pág. 38.

173 En un principio, dice, la idea era indeterminada, la forma y el concepto se buscaban mutuamente sin éxito al estar unidos tan sólo por un nexo exterior de continuidad, sin ser penetrados por la subjetividad de la que emana el ideal. Es la etapa del arte simbólico de Oriente, cuya forma intuitiva, en su intento por adecuar la materia, la empuja hacia lo monstruoso y se desfigura ella misma. Será en el arte clásico de Grecia y Roma donde, piensa el alemán, se manifieste con todo su esplendor la correspondencia entre el mundo y el espíritu, si bien, dado que dicha unidad se basa en una relación objetiva, sensible, la idea halla su expresión, y su pináculo, en la forma humana. Con la irrupción de la subjetividad, no obstante, el arte se habría vuelto romántico; ello, a causa del divorcio, principio y fuente de la cristiandad, entre lo verdadero y su representación sensible, una falta de concordancia que, a la intuición de la etapa simbólica, agrega la inteligibilidad de la representación. Cf. G. W. F. Hegel, Lecciones de estética, I (trad. de R. Gabás), Península, Barcelona, 1991, págs. 263-265.

174 Cf. loc. cit., II, págs. 86-90.

${ }^{175}$ Cf. J. M. Murry, El estilo literario (trad. de J. Hernández), Fondo de Cultura Económica, México, 1951, págs. 65-66. 
esta base, en su The Art of Satire (1940), David Worcester hablará de dos clases de invectiva. Ajena a la sátira, la primera de ellas poco se distinguiría del vejamen y la maledicencia; ahí entrarían, por ejemplo, los yambos de Arquíloco e Hiponacte. La segunda, de carácter propiamente satírico, exigiría en cambio cierta objetividad por parte de su autor, impelido por ello a ocultarse tras el lenguaje indirecto y los recursos estilísticos ${ }^{176}$. Sin este rodeo, «time-lag» lo llama el teórico, quedaría impedido el disfrute que a todo lector reporta acceder a los significados por él mismo y sentirse parte del selecto grupo que los comparte ${ }^{177}$.

De manera adicional, Worcester se refiere a la parodia como subespecie de la sátira, recurriendo a la distinción entre alto burlesque, donde entrarían tanto la parodia, con su imitación de una obra determinada, como la épica burlesca (mock-heroic), emuladora de todo un estilo literario, y bajo burlesque, que comprendería la caricatura y el travesti178. El criterio clasificatorio lo toma Worcester de Richmond Bond quien, en su English Burlesque Theory, 1700$-1750^{179}$, marca la distinción, por una parte, entre el enaltecimiento de un sujeto bajo y el rebajamiento de un sujeto noble y, por la otra, entre una variante de corte específico y una de carácter general. En el cuadro resultante, al alto burlesque corresponden la parodia y la épica burlesca en sus modalidades específica y general, respectivamente, tal como el travesti y el hudibrástico se acomodan, en el mismo orden, al burlesque bajo ${ }^{180}$, sin que, empero, entre las cuatro categorías exista un claro nexo amén de la enormemente variada incongruencia del burlesque. En este sentido, Worcester supera a su mentor al identificar la función crítica que subyace a la incongruencia, siendo que el bajo burlesque establece un estándar por debajo de la víctima a comparación del que ésta es juzgada por el lector, mientras que el burlesque alto evidenciaría los defectos de su víctima contrastándola con un estándar superior ${ }^{181}$. Con todo, el teórico reconoce la inutilidad de semejante criterio para caracterizar obras como la Batracomiomaquia, en las que ambos procedimientos aparecen juntos ${ }^{182}$, de donde su afán por detallar los recursos retóricos empleados por la parodia y, en general, por la sátira.

El primero y más importante, la ironía, respecto a la que cabe reprocharle a Worcester no sólo la vaguedad de su definición: «el resplandor resultante del

176 D. Worcester, The Art of Satire, Russell \& Russell, Nueva York, 1960, pág. 13 y sigs.

177 Cf. loc. cit., págs. 29-30 y 77.

${ }_{178}$ Cf. loc. cit., pág. 47 y sigs.

179 W. de Richmond Bond, English Burlesque Theory, 1700-1750, Harvard University Press, Cambridge, 1932, págs. 4-5.

${ }^{180}$ Entre 1663 y 1678, Samuel Butler publicó las tres partes de su Hudibras, donde cuenta la historia de un militar que, investido a sí mismo de la autoridad de un reformador puritano, abandona las armas que, por cierto, nunca usó y se entrega a toda clase de aventuras teñidas de vileza y vulgaridad.

${ }^{181}$ Cf. op. cit., págs. 44-46.

${ }^{182}$ Loc. cit., pág. 48. 
choque de dos absolutos en contradicción»183, sino también cierta incongruencia entre un presupuesto como «toda ironía es satírica, pero no toda sátira es irónica» ${ }^{184}$, y las dos clases de invectiva por él observadas. El desatino, que en Worcester no trasciende pues, si bien él no se percata de ello, el contraste entre lo alto y lo bajo que figura en la base de su análisis constituye un procedimiento netamente irónico, llevará, en cambio, a Ellen Douglass Leyburn a confundir lo que aquél llama time-lag de la sátira con la alegoría. Para esta autora, sátira y alegoría comparten una serie de características (v. gr., el empleo del lenguaje indirecto, la vívida representación de verdades universales, la economía de la figuración, la fijación de un estándar valorativo) que harían de su convivencia un imperativo para el autor de sátiras ${ }^{185}$. Su error consiste, empero, en equiparar el denuesto de la falta, cualidad esencial de la sátira, con la representación figurada de la virtud que toda alegoría contiene, de modo que la exhortación a la virtud que, según muchos teóricos, subyace a la sátira se confunde con la apología que implica toda representación figurada del ideal186. Cuando, en su sátira novena, Juvenal emplea recursos plásticos para referirse a los abusos que los patricios hacen de sus apellidos ilustres, el lenguaje figurado desempeña la función negativa de vulgarizar a los nobles, por lo que la figuración resulta, no alegórica, sino irónica ${ }^{187}$; a cambio, cuando el poeta exhorta a la virtud, se olvida por completo del lenguaje figurado e invoca: «Sé un buen soldado, un tutor honesto, también un juez íntegro»188. La propia Douglass Leyburn lo intuye cuando espera del autor de sátiras alegóricas la actitud imparcial del ironista, capaz de abstraerse de la contradicción ${ }^{189}$.

Ironía y sátira son dos términos ligados históricamente y cuya contigüidad ha sido causa de enormes confusiones. La mayoría de los teóricos contemporáneos que han abordado una u otra ha tratado, sin éxito, de señalar los límites entre ellas. Casi todos han optado, con mayor o menor apego, por la

${ }^{183}$ Loc. cit., pág. 165. La traducción es mía.

184 Loc. cit., pág. 81.

185 Cf. «Notes on Satire and Allegory», The Journal of Aesthetics and Art Criticism, 6, 4, 1948, págs. 323-331. Una visión análoga se encuentra en A. Pollard, Satire, Methuen, Londres, 1970, págs. $28-40$.

${ }^{186}$ Cf. E. Douglass Leyburn, art. cit., pág. 323.

187 Para comprender esta diferencia cabe recurrir a Victoria Arbizu-Sabater, quien dice de la Carajicomedia (s. XVI) que «se trata de una parodia contundentemente sexual del Laberinto de Fortuna de Juan de Mena [...]. Recuérdese que el Laberinto es una alegoría política en verso que fue presentada al rey Juan II en 1444, y que pretendió convertirse en el gran poema de exaltación de Castilla: si la intención de Mena era favorecer el fortalecimiento de los reinos que integraban esta corona y magnificar su grandeza histórica en tiempos de considerable turbulencia, la del anónimo autor de la Carajicomedia dirige sus pasos hacia una meta opuesta [...]. Y es que la Carajicomedia contiene un mensaje feroz y obsceno sobre la política, la sociedad y la moralidad de su época mediante una anti-exaltación del poder femenino a través de su sexualidad»: «Paratexto textual y sátira misógina en la Carajicomedia», Scriptura, 19/20, 2008, págs. 37-38.

188 «Esto bonus miles, tutor bonus, arbiter idem integer»: vv. 79-80, en op. cit., pág. 66.

189 Art. cit., pág. 330. 
distinción de Northrop Frye, que en su Anatomía de la crítica (1957) define la sátira como una «ironía militante cuyas normas morales, relativamente claras, asumen un estándar contra el que se miden el absurdo y lo grotesco» ${ }^{190}$. Para el canadiense, la sátira constituye una clase de ironía que lleva implícito un reproche moral; precisa, por tanto, de un objeto de ataque, al que se dirige mediante un rodeo pletórico de fantasía. En contraste, la ironía no satírica se referiría a un contenido de carácter realista, de donde su carencia, que yo no veo, de una actitud definida por parte del autor ${ }^{19}$.

Al margen de su concepción de la sátira como mythos ${ }^{192}$, misma que, así la del idealismo, apela a su espíritu transgenérico, la teoría de Frye acusa ciertas inconsistencias. En primer lugar, Alain Berrendonner ha señalado ya que toda ironía cumple una función defensiva porque, en mayor o menor medida, emana de una actitud crítica ${ }^{193}$, de lo contrario sería indistinguible de la paradoja pues, sacando a la luz la existencia de una incongruencia, la ironía se abstendría de emitir un juicio al respecto. Por cuanto al realismo del contenido irónico, para Jonathan Culler la exigencia de verosimilitud resulta innegable,

${ }^{190}$ N. Frye, Anatomy of Criticism. Four Essays, Princeton University Press, Nueva Jersey, 1957, pág. 223.

191 Cf. loc. cit., pág. 224

${ }^{192}$ Frye propone que la obra literaria se construye sobre estructuras míticas, cuya significación arquetípica agrupa en tres categorías del imaginario: apocalíptica, demoníaca y analógica. De acuerdo con esta hipótesis, la imaginería apocalíptica corresponde a las jerarquías mediante las que el hombre se relaciona con el ideal colectivo, transformado en divinidad; se manifiesta en la realidad como deseo de acceder a un mundo civilizado, a semejanza del divino, por medio del trabajo común, analogía que constata en la transformación de los tres aspectos no humanos del mundo: vegetal, animal y mineral: «The form imposed by human work and desire on the vegetable world, for instance, is that of the garden, the farm, the grove, the park. The human form of the animal world is a world of domesticated animals [...] The human form of mineral world, the form into which human work transforms stone, is the city» (loc. cit., pág. 141). Estas tres instancias bíblicas — la ciudad, el jardín y la oveja - constituyen para Frye los arquetipos elementales de toda imaginería apocalíptica. En oposición a ésta, la imaginería demoníaca representaría una sociedad alejada por completo del ideal; se trata del estado del mundo antes de que la imaginación humana comenzara a trabajar y se manifestaran sus primeras formas ordenadas. En estos dos imaginarios opuestos se apoyarían, respectivamente, los modos mitológico e irónico de la literatura. Por su parte, los estratos intermedios, el romance y los modos high mimetic (épica, tragedia) y low mimetic (comedia, realismo), se sustentan en la representación de un mundo mediano entre el apocalíptico y el demoníaco, correspondiente a la imaginería analógica. En esta categoría, el canadiense concibe la contraparte humana del apocalipsis como «analogía de la inocencia», a la que corresponde el modo romántico, y la representación divina de lo humano, como «analogía de la naturaleza y la razón», con la que se relacionan los modos altamente miméticos, mientras que las manifestaciones humanas del caos seminal y la humanización de éste, expuestas en los modos bajos, corresponden a la «analogía de la experiencia». Sobre esta base, Frye define la comedia como «mito de primavera», el romance como «mito de verano», la tragedia como «mito de otoño», y la ironía y la sátira como «mitos de invierno». Cf. loc. cit., págs. 33-239.

${ }_{193}$ Cf. A. Berrendonner, Elementos de pragmática lingüistica (trad. de M. Mizraji), Gedisa, Buenos Aires, 1987, pág. 197. 
pero sólo en tanto que vehículo para contravenir las convenciones de lo real ${ }^{194}$. Así ocurre en Una modesta proposición (1729), donde, según el propio Frye, Swift desarrolla un argumento satírico que, luciendo plausible, se disuelve en la inmoralidad y la fantasía. Lo inmoral no lo niego, pero lo fantástico..., a no ser que fantásticos sean, pienso, los jabones fabricados con sebo de judío ${ }^{195}$. La traba emana de la misma definición propuesta por el canadiense, pues si la ironía consiste en el residuo no heroico de la tragedia y, a un tiempo, la actitud moralmente crítica de un oráculo y una fortuna a propósito de Edipo, de Agamenón, no queda bastante clara, entonces no sé yo qué entender por actitud clara y precisa. Dónde queda, me pregunto, la ironía no satírica cuando, de acuerdo con Frye, las tres fases finales de la sátira corresponden precisamente a dicho residuo, a saber: (1) el aspecto moral que subyace a la caída del héroe, de donde la fase tolstoiana característica de Shakespeare y Conrad; (2) el modo de acertijo o rompecabezas que asume la fatalidad, fuente de la sátira metafísica de Browning y Hardy, y (3) la representación de la vida humana en los términos de una larga e irresoluta servidumbre, visión que arroja sátiras tan despiadadas como En la colonia penitenciaria (1914), de Kafka, y 1984 (1949), de Orwell196.

$\mathrm{Al}$ igual que Worcester, Frye también apuesta por las semejanzas entre sátira y comedia pero, a diferencia de aquél, para quien la risa cómica se distingue de la satírica por su relativa falta de propósito ${ }^{197}$, el canadiense articula el nexo en tres fases correspondientes a las tres etapas irónicas de la comedia ${ }^{198}$. En la primera fase, el sentido del absurdo no se percibe sino por fuera del texto. Se trata de la sátira, ¿o comedia?, de norma baja, cuya representación de una sociedad subvertida carecería, de no ser por la inclusión de un eirôn que sustituye al héroe convencional, de parámetros de comparación con el ideal; aquí entrarían lo mismo la sátira enciclopédica de la edad media y el Elogio de la locura (1511), de Erasmo, que La vida del difunto Jonathan Wild (1743), de Fielding. La segunda fase irrumpiría al momento de remplazar el modelo convencional por la ridiculización de las fuentes y los valores de la convención; entre sus formas más elementales se cuentan la sátira de escape, en la que, sin renunciar a la suya propia, tal como don Quijote (fase quijotesca, la llama Frye) y el pícaro,

194 Cf. J. Culler, La poética estructuralista. El estructuralismo, la lingüística y el estudio de la literatura (trad. de C. Manzano), Anagrama, Barcelona, 1978, pág. 219 y sigs.

195 A propósito, el esperpento de Valle-Inclán resulta grotesco, pero no fantástico. A fin de cuentas, bien dice Wittgenstein que «por muy diferente del real que se piense un mundo ha de tener algo en común con él» (Tractatus logico-philosophicus, 2.022, trad. de J. Muñoz e I. Reguera, Alianza, Madrid, 2003, pág. 51).

196 Cf. N. Frye, op. cit., págs. 236-239.

197 Cf. N. Frye, loc. cit., págs. 37-38: «if a sense of unity is produced by the common bearing of diverse illustrations, we are on the side of satire. If the operations of wit are promiscuous and casual, the presumption is in favor of comedy».

198 De las seis que le atribuye el teórico, las tres fases restantes de la comedia, de carácter idílico, entrarían en correspondencia con las fases idílicas del romance, a cuyos momentos heroicos se acomodan, de manera complementaria, las fases heroicas de la tragedia. Véase loc. cit., pág. 181 y sigs., 219 y sigs. 
el héroe huye rumbo a una sociedad más acorde con su naturaleza, y también los ingenuos que, como el de Voltaire (1767), chocan con la malicia de la sociedad representada. Esta técnica de desintegración conduciría a la tercera fase:

Second-phase satire may make a tactical defence of the pragmatic against the dogmatic, but here we must let go even of ordinary common sense as a standard. For common sense too has certain implied dogmas, notably that the data of sense experience are reliable and consistent ${ }^{199}$.

En esta sátira del desengaño o high norm satire figurarían, con sus mundos dislocados, Petronio, Apuleyo, Rabelais y Swift.

No es Frye, sin embargo, el único que ha tratado, sin éxito, de trazar límites claros entre sátira e ironía. Claudette Kemper sugiere, por ejemplo, que la sátira consiste en un «ataque que señala defectos precisos de la sociedad en términos de lo real», mientras que la ironía pone en juego una ambigüedad epistemológica ${ }^{200}$. Pretende esta autora distinguirlas mediante la oposición de los binomios convicción / libertad, estabilidad / inestabilidad, moralidad / amoralidad y sociedad / individuo, de modo que la sátira sería producto de una convicción y, por tanto, dirigiría a la sociedad un juicio de carácter moral, cuando que la ironía nacería de un librepensar que, consecuentemente, se abstendría de emitir juicios y que, ajeno a lo moral, pondría sus ojos en el individuo ${ }^{201}$. Cabe objetar, primero, que tan sólo el acto de expresarse libremente por la vía negativa obedece a una convicción: «no elegir - dice Vladimir Jankelevitch- es también una manera de elegir» ${ }^{202}$. Señalar una incongruencia acarrea, por fuerza, la convicción de que, como tal, posee una contraparte congruente: «Cuando alguien señala que algo ha sido hecho incorrectamente - dice Leonard Feinberg - da a entender que existe un modo correcto de hacerlo» ${ }^{203}$, pero no necesariamente que conoce dicho modo:

La conciencia que ve las faltas de la sociedad rara vez es la clase de conciencia que vislumbra las soluciones. No hay motivo por el que deba poseer dos dones en lugar de uno $^{204}$.

Toda ironía, por otra parte, tiende a la inestabilidad, pero no veo cómo puede resultar estable un lenguaje que critica a la sociedad y, encima, lo hace soterradamente y con apoyo de la fantasía. Al margen de lo fantástico, me parece que el único modo eficaz de criticar a la sociedad es por medio del

${ }^{199}$ Loc. cit., pág. 234. Para una caracterización de la sátira romana como defensa del sentido común y la filosofía popular, véase C. W. Mendell, art. cit.

200 Cf. C. Kemper, «Irony Anew, with Occasional Reference to Byron and Browing», Studies in English Literature, 7, 1967, pág. 715.

${ }^{201}$ Cf. loc. cit., págs. 705-719.

202 V. Jankelevitch, La ironía (trad. de R. Pochtar), Taurus, Madrid, 1982, pág. 140.

${ }^{203}$ L. Feinberg, Introduction to Satire, pág. 11. La traducción es mía.

${ }^{204}$ Loc. cit., pág. 15. 
individuo, en el que se manifiestan las imperfecciones de aquélla ${ }^{205}$. Horacio no dice, sin más, «la necedad es mala»; dice «los necios, cuando evitan un defecto, caen en el opuesto. Maltino se pasea arrastrando la túnica; otro se la levanta con descaro hasta la ingle. Rufilio huele a pastillas; Gorgonio a macho cabrío» ${ }^{206}$. Aún así, para los fines de la literatura, los defectos de una persona, de un personaje, no tienen valor sino como reflejo de un mal cultural, histórico, económico, estético...207 Empatar, pues, lo satírico y lo moral implica afirmar que los defectos de la sociedad se reducen a tal orden, de ahí que más valga convenir con Feinberg en que «la sátira actúa sobre la totalidad de las actividades humanas y los parámetros que la sostienen pueden ser metafísicos o sociales o morales» ${ }^{208}$.

Para el Gilbert Highet de The Anatomy of Satire (1962), la ironía constituye, en cambio, tan sólo un arma retórica al servicio de la sátira, categoría que compartiría con procedimientos estilísticos tan diversos como la paradoja, la antítesis, la parodia, la obscenidad y la exageración ${ }^{209}$. Highet reduce la ironía a una de las técnicas con que cuenta el autor de sátiras; esto es, el empleo de máscaras, especie a la que también pertenecería el sarcasmo, definido como una ironía que destaca por su claridad y su amargura210. De mayor jerarquía resulta, para Highet, el registro paródico, toda vez que, asegura, la sátira suele cobrar la forma o bien de un monólogo, donde, como Juvenal, el autor habla por sí mismo, o bien de una parodia, cuando éste se oculta detrás de una máscara conocida, así en la reconstrucción del fantasma de Settle por parte de Pope, o bien de una narración, en cuyo caso el autor se oculta del todo para contar una historia, a la manera del Cándido, o representar una ficción dramática, como hace Shakespeare en Troilo y Cressida (c. 1602). Al tiempo que monólogo y narración se distinguen con claridad, resultando en clases equivalentes y, me pregunto, ¿mutuamente excluyentes?, Highet reconoce que la parodia suele presentarse en la forma de uno u otra, por lo que, acotando su clasificación, hablará de parodia, monólogo no paródico y ficción no paródica como de las tres modalidades satíricas ${ }^{21}$. Lo interesante es que, pese a la distinción, cuando se ocupa de los recursos estilísticos y retóricos de los autores de prédicas y ficciones satíricas, el catedrático de Columbia se muestra incapaz de prescindir del término parodia que, además de para señalar las

${ }^{205}$ Ahí está Robinson Crusoe en la soledad de su isla, deshumanizándose sin la ayuda de la sociedad.

${ }^{206}$ Horacio, Satirae, I 2, vv. 24-27, en ed. cit., pág. 7.

207 Se trata de los factores funcionales que, según el formalismo ruso, integran los diversos elementos del material. Para los formalistas, «un elemento estaba motivado si tenía una función en el texto literario, y en principio todos los elementos de una obra de arte lograda debían estar motivados» (J. Culler, op. cit., pág. 227); es decir que, en el marco de una obra, toda ironía cumple una función y, por tanto, no aspira a la total libertad.

${ }^{208}$ L. Feinberg, Introduction to Satire, pág. 12.

${ }^{209}$ G. Highet, op. cit., pág. 18.

${ }^{210}$ Cf. loc. cit., págs. 55-61.

${ }^{211}$ Cf. loc. cit., págs. 13-14. 
semejanzas entre sátira y comedia ${ }^{212}$, emplea para referirse, caso de los autores de monólogos, a Bion, Xenófanes, Erasmo y Roy Campbell, así como al autor de la Batracomiomaquia, a Seneca, con su Apocolocintosis, y a Quevedo con sus Sueños, estos últimos representantes de la ficción satírica ${ }^{213}$. Con todo, cuando menos en sentido estricto, Highet concibe la parodia de manera acertada, lo que consta en la siguiente declaración, por lo demás, una respuesta anticipada a Linda Hutcheon:

Si una copia entretiene al público y lo deleita con la exactitud de la imitación pero no sacude su admiración por el original, haciéndolo sentir un desdén hacia él en virtud de una debilidad antes no percibida, entonces no se trata de una parodia o una sátira. Pero si la copia socava el original, bien sea sutilmente, señalando sus faltas, revelando sus imposturas ocultas, subrayando sus debilidades y carencias, entonces se trata de una parodia satírica [...] La parodia constituye, así, una de las principales improntas de la sátira; se la puede definir como una imitación que, mediante la distorsión y la exageración, convoca al placer, la burla y, en ocasiones, al desprecio ${ }^{214}$.

A diferencia de Frye, para quien, en la sátira, lo fantástico opera como parámetro de comparación, Highet recupera el esquema de contraste entre realidad e ideal propuesto por Schiller y le suma la distorsión como técnica básica de lo que el alemán refiere en términos de tratamiento estético del objeto. Al tiempo que aparenta ceñirse a la realidad, la ficción satírica, dice el escocés, se desmiente a sí misma sometiendo su objeto a constantes distorsiones ${ }^{215}$, de ahí que Feinberg comience su Introduction to Satire (1967) asegurando que «[...] como otras artes, la mejor sátira concierne a la naturaleza de la realidad $\mathrm{y}$, a diferencia de otras artes que enfatizan lo que es real, la sátira enfatiza lo que parece real pero no lo es» $\rangle^{216}$.

Pese a renegar de las definiciones categóricas ${ }^{217}$, para Feinberg la sátira consiste en una distorsión crítica y jocosa de lo familiar cuya mira comprende así al individuo como a la sociedad, a los que se dirige conducida por la ironía y la invectiva ${ }^{218}$. Como hace ver John Erickson en su reseña del libro ${ }^{219}$, semejante postura asigna a la sátira las facetas cómica y crítica atribuidas por Worcester

212 Véase loc. cit., pág. 29. Dice, a propósito, que así como la invectiva se sitúa en un extremo de la sátira, en el otro se hallan la comedia y la farsa, que se burlan del sujeto sin llegar a ofenderlo. Cf. loc. cit., págs. 154-155.

213 Véase loc. cit., págs. 32, 36, 49, 53, 166, 169 y 187.

${ }^{214}$ Loc. cit. pág. 68. Mía la traducción.

${ }^{215}$ Cf. loc. cit., págs. 158-160.

${ }^{216}$ L. Feinberg, Introduction to Satire, pág. 3.

217 Véase L. Feinberg, «Satire: the Inadequacy of Recent Definitions», Genre, 1, 1, 1968, págs. 31-37.

${ }^{218}$ L. Feinberg, loc. cit., págs. 4, 18-19.

${ }^{219}$ Véase J. Erickson, «Feinberg, Leonard, Introduction to Satire», Comparative Literature, 21, 4, 1969, pág. 367. 
a la risa, a lo que se suma que el concepto de lo familiar, «the substance of life», conduce a Feinberg a incorporar la sátira al realismo ${ }^{220}$. Tampoco este autor, señala Erickson, establece límites claros entre sátira e ironía, pues por ningún lado figura una definición de la segunda, constantemente calificada de «socrática», «cósmica» y demás ${ }^{221}$. Su más grave error estriba en que, aun llegando a conclusiones acertadas, Feinberg parte de una endeble concepción de la sátira. Habla, por ejemplo, de la disimulación como de su fuente más pródiga y, dando en un clavo en el que, que yo sepa, no se había dado, sitúa la hipocresía como objeto primordial del escarnio satírico; hasta aquí, todo bien, pero de inmediato aparecen Sócrates y su ironía como enemigos del hipócrita, definido, en atención a Aristóteles y Teofrasto, como quien pretende ser lo que no es, y en ningún momento aclara el teórico que, en la misma tradición peripatética, es la ironía la que se opone a la hipocresía ${ }^{222}$.

Por su parte, en su Satire (1969), Matthew Hodgart retomará la vieja concepción de la sátira ligada a lo ridículo, que se agrega al imperativo fantástico de un Frye, y cifrada en la técnica reductiva de la que da cuenta Cascales y que consistiría en rebajar la estatura de la víctima en los planos del argumento, el estilo y la retórica ${ }^{223}$. Además, Hodgart recupera de Worcester el sentimiento de superioridad que sobreviene en el lector cuando, por encima del objeto de escarnio, descifra la intención autoral, si bien reconoce que, para que la sátira se convierta en arte, tal sentimiento ha de brindar al lector un placer puro, un efecto estético ${ }^{224}$. Los recursos satíricos se dirigen, asegura, a incitar el ingenio del lector para que, de modo aparentemente casual, se convierta en atacante por derecho propio ${ }^{225}$. Este renovado interés por el lector va de la mano del cambio de perspectiva introducido por la escuela de Constanza en la teoría literaria ${ }^{226}$, que a partir de los años sesenta, emulando a la filosofía analítica en el marco de la lingüística, presta atención a los procesos mediante los que el lector naturaliza el texto literario. En esta órbita, Koenraad Kuiper ha propuesto que, en ausencia de indicadores de la intención autoral, el lector debe decidir si lo que lee constituye o no una sátira ${ }^{227}$. Sólo así, y en lo secundario, percibiría la intención del autor, que cobraría relevancia únicamente al resolverse el carácter de la recepción ${ }^{228}$. En adición al de la falacia intencional, Wimsatt y

${ }^{220}$ Cf. L. Feinberg, Introduction to Satire, pág. 99.

${ }^{221}$ Véase J. Erickson, loc. cit., pág. 367.

222 Cf. L. Feinberg, op. cit., págs. 23-31.

${ }^{223}$ Cf. M. Hodgart, La sátira (trad. de Á. Guillén), Guadarrama, Madrid, 1969, pág. 115.

${ }^{224}$ Loc. cit., pág. 25.

${ }^{225}$ Cf. loc. cit., pág. 108.

${ }^{226}$ Cf. H. R. Jauss, «Cambio de paradigma en la ciencia literaria» (trad. de S. Franco), en D. Rall (ed.), En busca del texto. Teoría de la recepción literaria, Universidad Nacional Autónoma de México, 1993, págs. 59-71.

227 Véase K. Kuiper, «The Nature of Satire», Poetics, 13, 6, 1984, pág. 469.

${ }^{228}$ Loc. cit., pág. 472. En el otro polo, Feinberg dedica The Satirist: His Temperament, Motivation and Influence (Iowa State University Press, Ames, 1964) a descifrar, intelectual y emocionalmente, al autor de sátiras. 
Beardsley advierten, a propósito, el peligro de la falacia afectiva que, lo mismo que aquélla, conduce a la desaparición del texto como objeto de la crítica ${ }^{229}$. De hecho, amén de las advertencias explícitas, Highet identifica cuando menos tres clases de indicadores textuales: la remisión a un texto satírico anterior, como hace Erasmo en su Elogio con la Batracomiomaquia, el empleo de técnicas propias del género, tal como en la sátira primera de Boileau abundan los recursos empleados por Juvenal en su tercera y, en especial, la presencia de un sentimiento en el que confluyen el deleite y el desprecio ${ }^{230}$.

Los estudios sobre la sátira adolescen en que, pese a calificarla de forma literaria, la gran mayoría la ha definido según su temática, de modo que la teoría tiende a convertirse en un listado de tópicos. De ahí que, en «La sátira y sus principios organizadores», de 1973, George Peale distinga el aspecto formal del texto satírico, la «etiqueta de procedimientos y elementos técnicos que funcionan decorativamente», del espíritu que lo rige: «una visión del mundo que, por el mero hecho de estar cristalizada por escrito, revela algún motivo intencional» ${ }^{231}$. Por cuanto a su instrumental retórico, Peale asegura que la sátira apela al modo noético del lenguaje, en oposición al dianoético, pues en lugar de presentar su tesis discursivamente lo hace, y aquí el autor sigue a Sussane Langer ${ }^{232}$, por medio de un complicado juego de operaciones expresivas cuya suma deviene una forma significativa ${ }^{233}$. Se inclina, empero, por la reducción como técnica básica, misma que, mediante metáforas, máscaras y profusiones escénicas y lingüísticas, remplazaría los atributos de la realidad por cualidades paródicas y, en ocasiones, irónicas, como en el caso del dómine Cabra en El buscón, de Quevedo ${ }^{234}$. Respecto al sustrato intencional, el catedrático de la Universidad de Kansas conviene en que la sátira precisa de un blanco y, como Feinberg, reconoce su tendencia a representar no el ideal, sino la realidad ${ }^{235}$. El criterio moral le parece, pues, insuficiente: «No es forzoso - dice - que se implique una decisión acerca del relativo bien o mal ontológico del objeto de ataque. Por esto considero que los propósitos de la sátira son éticos, pero no necesariamente morales» ${ }^{236}$.

A medida que, en el ocaso del siglo XX, declinó el interés por la sátira tradicional, el afecto por la menipea vino al alza. El auge se debe a Bajtín y, en menor grado, a Frye. Tan sólo el primero propone catorce características básicas del

${ }_{229}$ Wimsatt y Beardsley, «The Affective Fallacy», en H. Adams (ed.), Critical Theory since Plato, Harcourt Brace Jovanovich College, Fort Worth, 1992, pág. 952.

${ }^{230}$ Cf. G. Highet, op. cit., págs. 14-23.

231 Proemio, 4, 1-2, 1973, pág. 190.

${ }^{232}$ Véase S. Langer, Sentimiento y forma (trad. de M. Cárdenas y L. O. Hernández), Universidad Nacional Autónoma de México, 1967, págs. 32-48.

${ }^{233}$ G. Peale, «La sátira y sus principios organizadores», Prohemio, IV, 1-2, 1973, 189-211, págs. 201-202, 1973, págs. 201-202.

${ }^{234}$ Cf. loc. cit., pág. 202 y sigs.

235 Véase L. Feinberg, The Satirist, págs. 34-41.

${ }^{236}$ G. Peale, op. cit., pág. 200. 
género 237 ; destacan el elemento carnavalesco de la risa, las situaciones extraordinarias que, justificando el empleo de la fantasía, ponen a prueba la veracidad del discurso, la presencia de un naturalismo de bajos fondos, la estructuración tripartita de la acción, que viaja de la tierra al Olimpo o a los infiernos, la observación desde un punto de vista inusitado, las alturas, por ejemplo, la inclusión de utopías sociales mediante ensoñaciones o viajes a tierras ignotas, la incorporación de géneros intercalados $\mathrm{y}$, en general, el tratamiento de temas actuales y familiares. Inspirado en Burton, Frye llamará al género anatomía, asignándole la función de tratar menos de personas que de actitudes mentales, figuras caricaturescas en cuyas enfermedades del intelecto se cifrarían los males sociales ${ }^{238}$. Con todo, ahí donde para Bajtín la menipea constituye, con el diálogo socrático, el antecedente directo de la novela polifónica ${ }^{239}$, recurriendo a ejemplos contemporáneos como Un mundo feliz (1932), de Huxley, el canadiense las sitúa en idéntica jerarquía, como variantes de la prosa de ficción junto a la confesión y el romance 240 .

Pesa Bajtín en autores como Relihan y Lía Schwartz Lerner, esta última atenta al carácter híbrido y dialógico de la sátira ${ }^{241}$, mientras que Frye se cuela a nuestro siglo por la vía de Carter Kaplan quien, en su Critical Synoptics: Menippean Satire and the Analysis of Intellectual Mythology242, comprende la anatomía como una técnica de análisis sinóptico que, mediante la narración de historias, se ocupa de los usos que se dan a las palabras. Tampoco Howard Weinbrot se anima a ver en la menipea un género literario; a cambio, su Menippean Satire Reconsidered (2005) la define como un variado conjunto de dispositivos que da soporte al tratamiento de un tema con severidad, así en Luciano y Petronio, o bien con condescendencia, como en Séneca, pero siempre cuestionando la falsa ortodoxia ${ }^{243}$. Dice, por cierto, Matthew Williams que la menipea del siglo XVIII solía, por el contrario, defender ideas conservadoras (pienso en los más recientes Kipling y Golding), de ahí que, haciendo gala de moderación, este autor la conciba más bien como un espacio de resistencia ${ }^{244}$.

${ }^{237}$ Cf. M. Bajtín, Problemas de la poética de Dostoievski (trad. de T. Bubnova), Fondo de Cultura Económica, México, 2003, págs. 166-173.

${ }^{238}$ Cf. N. Frye, op. cit., págs. 308-312.

239 Véase M. Bajtín, Problemas de la poética de Dostoievski, pág. 160.

240 Véase N. Frye, op. cit., págs. 312-314.

${ }^{241}$ Véase, L. Schwartz Lerner, «Golden Age Satire: Transformations of Genre», Modern Language Notes, 105, 2, 1990, pág. 279.

${ }^{242}$ C. Kaplan, Critical Synoptics: Menippean Satire and the Analysis of Intellectual Mythology, Fairleigh Dickinson University/Associated University, Madison y Londres, 2000, pág. 22 y sigs.

${ }^{243}$ H. Weinbrot, Menippean Satire Reconsidered, John Hopkins University Press, Baltimore, 2005, págs. 4-7.

${ }^{244}$ M. Williams, «Great Anarch's Ancient Reign Restor'd:» Menippean Satire and the Politics of Knowledge in the British Enlightenment, City University of New York, 2008, pág. 49. 


\section{A modo de cierre}

Me llama la atención que, ahí donde para los teóricos de la parodia ha pasado desapercibida la segunda plataforma semiótica del texto, aquella que, oculta tras el intertexto paródico, conforma la infraestructura que determina el excedente de sentido ${ }^{245}$, los académicos atentos a la sátira suelen ignorar la superestructura de los textos. Dando por sentado que su técnica básica es la caricatura, la reducción, el rebajamiento, ¿la parodia?, y enfocándose en los motivos predilectos del autor satírico, la gran mayoría de los especialistas pasa sin atender al verdadero conflicto ideológico que la sátira pone sobre la mesa: la lucha de clases, donde «clase» se refiere al ordenamiento jerárquico que conduce del objeto a su representación, de la temática a la tópica. En ausencia de este principio, los temas figuran como elementos aislados, carentes de un hilo conductor más allá del deseo, siempre identificado por los teóricos, rara vez reconocido por los autores, de corregir los vicios y enmendar a la especie. El error, del que pocos, como Schwartz Lerner, se salvan, estriba en dejar de preguntarse qué tienen en común la diatriba, el sueño, el descenso al inframundo, el viaje a tierras desconocidas, la fábula de animales o el simposio paródico. Tras un análisis de los motivos típicos de la menipea, esta autora reconoce en el dialogismo y la hybris los rasgos comunes de la tradición satírica, en la que invariablemente observa una confluencia problemática de voces ${ }^{246}$, si bien pasa por alto que, en todos los casos, se trata de motivos espaciales orientados, por una parte, a acentuar el contraste entre realidades semejantes: vivos más muertos que los muertos, animales que se comportan como humanos, comensales que, pese a su postura adversa, honran el festín con singular alegría... Por otra parte, y aquí es donde los esquemas teóricos se desdibujan, semejantes configuraciones espaciales, semejantes tópicos, ponen de relieve la distinción que media entre las formas que, en representación de dichas realidades, conviven en el universo planteado por el texto: formalmente hablando, ni los cerdos se parecen a los militares, ni Gulliver se parece a un caballo ni los dependientes se parecen a sus amos. No sólo no se parecen; son sumamente contrastantes, pero al ponerse unos junto a los otros, resulta que se describen mutua y recíprocamente, que la clase de desatinos cometidos por los unos es inversamente complementaria a la clase de desatinos atribuibles a los otros.

A simple vista, se observa un desplazamiento que va de la sustancia a la forma, de los constituyentes semánticos a los exponentes léxico-gramaticales; y sí, en sentido amplio así ocurre, toda vez que, en la constitución del significado satírico, el concepto, la idea, acaba situándose en el punto de cruce de dos formas distintas, de donde la imposibilidad de acceder por su medio a conocimiento positivo alguno. En sentido estricto, sin embargo, es la forma la

${ }^{245}$ Véase J. Campesino, «La parodia en el tiempo», Analecta Malacitana, XXXIX, 2016-2017, págs. 247-276. Caso atípico, en este sentido, el de Yuri M. Lotman (Estructura del texto artístico, trad. de V. Imbert, Istmo, Madrid, 1988, págs. 353-354).

${ }^{246}$ Cf. L. Schwartz Lerner, art. cit. 
que se vuelca sobre la sustancia, trasladando el análisis del sistema al proceso, del repertorio a la cadena, y regulando así la distancia que media entre los constituyentes, entre los objetos (no personas, recuérdese: actitudes mentales) que el texto conjunta. Dicho de otro modo, al desplazar el eje de las categorías sobre el eje de los acontecimientos, la sátira reduce (o amplía, según se vea) los objetos a clases, a tópicos, posibilitando con ello su análisis conceptual, y al mismo tiempo trata las denominaciones como elementos sintéticos, retóricos, en los que confluyen, no sin conflicto, valores de cambio y valores de uso. Este análisis sinóptico que Kaplan extrapola de la filosofía analítica y que, a grandes rasgos, opera por saturación (sobrecarga el objeto de elementos conceptuales), implica un cuestionamiento radical de la invariabilidad que, según el idealismo, distingue a las formas de representación, pues la inversión pone en evidencia que, a realidades invariables: la necedad y la picardía, la estupidez y la agudeza, la presunción y la humildad: la alazonía y la ironía ${ }^{247}$, corresponden formas comunes de representación (a la discreción de un objeto, una gama continua de figuras; he ahí la saturación), o bien que las mismas máscaras están a disposición tanto del simulador como del disimulador. Gulliver es tan enano como gigante según se lo compare con los habitantes de Brobdignag o bien con los de Liliput; el anciano decadente se burla de la mocedad tanto como la lozanía del joven se mofa de la decrepitud, lo que sin duda ocurre en la antigua figura de terracota con que Bajtín ilustra la imagen bicorporal248, imagen de la que, por lo demás, los sátiros son ejemplo emblemático.

Cabe, por último, añadir que toda tópica se enuncia mediante una retórica particular que, por tratarse de una crítica velada, en el caso de la sátira corresponde a la parodia, donde la crítica se disfraza de otra cosa al grado de llegar a eclipsar, aunque nunca del todo, la semejanza de la imitación. No existe, en este sentido, como propone, entre otros, Gerard Genette ${ }^{249}$, un grado cero de la parodia o de la sátira; la parodia es satírica en la medida en que se contrasta internamente, y a la inversa, la sátira es paródica en tanto que disfraza la crítica de otra cosa. Me interesa aclarar el asunto en consideración de que, si la parodia opera como forma del contenido irónico, la sátira procede a modo de sustancia de dicho contenido, en una metasemiología de alcances éticos resultante de la combinación problemática de una semiótica connotativa y un metalenguaje no científico ${ }^{250}$.

${ }^{247}$ Cf. Aristóteles, Ética nicomaquea, II 7, 1108a; IV 7, 1127a-b.

${ }^{248}$ Cf. M. Bajtín,, La cultura popular en la Edad Media y en el Renacimiento (trad. de J. Forcat y C. Conroy), Alianza, Madrid, 2003, pág. 29 y sigs., 391.

${ }^{249}$ Véase G. Genette, Palimpsestos. La literatura en segundo grado (trad. de C. Fernández), Taurus, Madrid, 1989, pág. 32 y sigs.

${ }^{250}$ Cf. L. Hjelmslev, Prolegómenos a una teoría del lenguaje (trad. de J. L Díaz de Liaño), Gredos, Madrid, 1974, págs. 160-173. 
